\title{
De arbeidsmarktperspectieven voor klinisch psychologen tot 1995
}

Citation for published version (APA):

Beekman, T. B. J., \& Heijke, J. A. M. (1990). De arbeidsmarktperspectieven voor klinisch psychologen tot 1995. Researchcentrum voor Onderwijs en Arbeidsmarkt, Faculteit der Economische Wetenschappen. ROA Reports No. 3 https://doi.org/10.26481/umarep.1990003

Document status and date:

Published: 01/01/1990

DOI:

10.26481/umarep.1990003

Document Version:

Publisher's PDF, also known as Version of record

\section{Please check the document version of this publication:}

- A submitted manuscript is the version of the article upon submission and before peer-review. There can be important differences between the submitted version and the official published version of record.

People interested in the research are advised to contact the author for the final version of the publication, or visit the DOI to the publisher's website.

- The final author version and the galley proof are versions of the publication after peer review.

- The final published version features the final layout of the paper including the volume, issue and page numbers.

Link to publication

\footnotetext{
General rights rights.

- You may freely distribute the URL identifying the publication in the public portal. please follow below link for the End User Agreement:

www.umlib.nl/taverne-license

Take down policy

If you believe that this document breaches copyright please contact us at:

repository@maastrichtuniversity.nl

providing details and we will investigate your claim.
}

Copyright and moral rights for the publications made accessible in the public portal are retained by the authors and/or other copyright owners and it is a condition of accessing publications that users recognise and abide by the legal requirements associated with these

- Users may download and print one copy of any publication from the public portal for the purpose of private study or research.

- You may not further distribute the material or use it for any profit-making activity or commercial gain

If the publication is distributed under the terms of Article $25 \mathrm{fa}$ of the Dutch Copyright Act, indicated by the "Taverne" license above, 
DE ARBEIDSMARKTPERSPECTIEVEN VOOR KLINISCH PSYCHOLOGEN TOT 1995

ROA-R-1990/3

Th.B.J. Beekman

J.A.M. Heijke

RESEARCHCENTRUM VOOR ONDERWIJS EN ARBEIDSMARKT

Faculteit der Economische Wetenschappen

Rijksuniversiteit Limburg

Maastricht, juni 1990 
CIP-GEGEVENS KONINKLIJKE BIBLIOTHEEK, DEN HAAG

Beekman, Th.B.J.

De arbeidsmarktperspectieven voor klinisch psychologen tot 1995/ Th. B.J. Beekman, J.A.M. Heijke. - Maastricht: Researchcentrum voor Onderwijs en Arbeidsmarkt, Faculteit der Economische Wetenschappen, Rijksuniversiteit Limburg met lit. opg.

ISBN $90-5321-037-7$

SISO 318.7 UDC [331.5:159.97-057.85] "313"

Trefw.: arbeidsmarkt; klinisch psychologen; toekomst. 
2. BESCHRIJVING VAN DE METHODE

2.1. Afbakening onderzoeksgroep en prognoseperiode

2.2. Overzicht van beschikbare databronnen 4

2.3. Bepaling van het toekomstig aanbod van klinisch psychologen 5

2.4. Bepaling van de toekomstige vraag naar klinisch psychologen

3. AANBOD VAN KLINISCH PSYCHOLOGEN 9

3.1. Inleiding 9

3.2. Uitstroom uit de universiteiten 9

3.3. Prognose van het aantal afstudeerders 1990-1995 10

3.4. Arbeidsaanbod van werkzoekende klinisch psychologen 12

3.5. Het totale arbeidsaanbod van klinisch psychologen 13

4. VRAAG NAAR KLINISCH PSYCHOLOGEN

4.1. Inleiding 15

4.2. Bepaling van relevante sectoren $\quad 15$

4.3. Werkgelegenheid per sector 18

4.4. Overzicht van relevante toekomstramingen 21

4.5. Vervangingsvraag 22

4.6. Vraag naar klinisch psychologen tot 1995

4.7. Arbeidsduurverkorting en deeltijdarbeid 26

4.8. Voorlopige prognose 27

5. RESULTATEN VAN DE DESKUNDIGEN-INTERVIEWS 29

5.1. Inleiding 29

5.2. Intramurale gezondheidszorg 30

5.2.1. Algemene ziekenhuizen 30

5.2.2. Intramurale en semimurale psychiatrische zorg 30

5.2.3. Verpleeghuizen 33

5.2.4. Zwakzinnigeninrichtingen 34

5.2.5. Medische kindertehuizen en kleuterdagverblijven en inrichtingen voor zintuiglijk gehandicapten 35 
5.3. Extramurale gezondheidszorg 36

5.3.1. Schoolartsendiensten 36

5.3.2. RIAGG 36

5.3.3. CAD 37

5.3.4. Eerstelijnspraktijken en samenwerkingsverbanden 37

5.4. Justitie 39

5.5. Kruisverenigingen 41

5.6. Buitenland 42

5.7. Nieuwe terreinen 42

5.8. Conclusies van de deskundigen-interviews 43

5.9. Interpretatie van de resultaten van de interviews voor de prognose 44

6. CONFRONTATIE VAN VRAAG EN AANBOD: TWEE VARIANTEN 46

6.1. Varianten 46

6.2. Confrontatie van vraag en aanbod 46

6.3. Conclusie 47

LITERATUURLIJST

BIJLAGE 1: Overzicht van de gegevens in het NIP-ledenbestand

BIJLAGE 2: Studierichtingen die kunnen opleiden tot klinisch psycholoog

BIJLAGE 3: Prognose van het aantal afstudeerders

BIJLAGE 4: Kenmerken van werkzoekende klinisch psychologen

BIJLAGE 5: Bezette arbeidsplaatsen in de intramurale gezondheidszorg per 31 december

BIJLAGE 6: Arbeidsvolume in de extramurale zorg

BIJLAGE 7: Verdeling van de NIP-psychologen naar werksector (afgestudeerd na 1984)

BIJLAGE 8: Gegevens van eerstelijns psychologen (dd. 6-1988)

BIJLAGE 9: SCP-raming personeel, in duizendtallen, 1983-1990

BIJLAGE 10: Prognose voorzieningengebruik intramurale zorg 1988-1995

BIJLAGE 11: Berekening van de vervangingsvraag

BIJLAGE 12: De arbeidsduur in de intramurale gezondheidszorg

BIJLAGE 13: Lijst met gespreksthema's 
VERANTWOORDING

Dit rapport vormt het verslag van een onderzoek naar de arbeidsmarktperspectieven voor klinisch psychologen. Deze studie werd verricht in opdracht van het Nederlands Instituut van Psychologen (NIP). De studie werd mede mogelijk gemaakt door een subsidie van het Ministerie van Welzijn, Volksgezondheid en Cultuur.

Het onderzoek werd onder leiding van prof. dr. J.A.M. Heijke uitgevoerd door drs. Th.B.J. Beekman. Drs. J.W. van Dam verleende assistentie bij het onderzoek, met name bij het afnemen van de deskundigen-interviews.

Het onderzoek werd begeleid door een hiervoor ingestelde commissie. De samenstelling van deze commissie was als volgt:

$M r$. R.F. Baneke, secretaris

Prof. dr. P.E. Boeke

Drs. J.F.A.M. van Dijk

Prof.dr.J.J. Dijkhuis, voorzitter

Drs. F.J.S. Donker

Dr.J.R.M. van Ratingen

Zonder de bijdrage van de leden van de begeleidingscommissie en de gesprekspartners, die bereid waren ons uitvoerig te woord te staan, was het onmogelijk geweest dit onderzoek uit te voeren. Wij zijn in het bijzonder dank verschuldigd aan Mr. R.F. Baneke, juridisch medewerker van het NIP, die ons voorzag van studiemateriaal en gecodeerde arbeidsmarktgegevens uit het NIP-ledenbestand en de contacten legde met de geïnterviewde deskundigen. 


\section{INLEIDING EN PROBLEEMSTELLING}

Dit rapport vormt het eindverslag van een studie naar de arbeidsmarktperspectieven voor klinisch psychologen. Deze studie is door het Researchcentrum voor Onderwijs en Arbeidsmarkt (ROA) verricht in opdracht van het Nederlands Instituut van Psychologen (NIP). De studie werd mede mogelijk gemaakt door een subsidie van het Ministerie van Welzijn, Volksgezondheid en Cultuur. Met de studie werd beoogd het opstellen van prognoses van de arbeidsmarktperspectieven voor klinisch psychologen in de periode 19901995, door de verwachte vraag naar klinisch psychologen te relateren aan het verwachte aanbod in die periode.

Bij het verstrekken van de opdracht tot deze studie heeft mede een rol gespeeld de overweging dat de invoering van de wet op de Beroepen in de Individuele Gezondheidszorg van invloed zal zijn op de positie van de psychologen in de gezondheidszorg (in de wet 'klinisch psychologen' genoemd). In dat verband wordt een belangrijke vraag hoeveel psychologen in het veld van de gezondheidszorg moeten worden opgeleid. Ter beantwoording van die vraag zijn een bepaling van het aantal psychologen dat thans werkzaam is in de gezondheidszorg en een studie naar de arbeidsmarktperspectieven voor klinisch psychologen noodzakelijk.

Door de Nationale Raad voor de Volksgezondheid (NRV) wordt een psycholoog omschreven als 'iemand die aan een universiteit of hogeschool het doctoraal examen in de psychologie met goed gevolg heeft afgelegd' en een klinisch psycholoog als 'de psycholoog die werkzaam is in de individuele gezondheidszorg en als zodanig is geregistreerd in de regeling ter registratie van psychologen werkzaam op het gebied van de klinische psychologie'. In dit rapport zal evenwel geen rekening worden gehouden met de vraag of de klinisch psycholoog reeds als zodanig geregistreerd is door het NIP. Na invoering van de wet-BIG zal het voor de hand liggen dat van psychologen die werkzaam zijn in de gezondheidszorg inschrijving in het BIG-register voor klinisch psychologen verlangd wordt. Als definitie van klinische psychologie wordt hier gebruikt 'de op het individu met een probleem of stoornis gerichte psychologie. Voorop staat daarbij de verandering van gedrag of belevingen van het individu' (NRV, 1988).

Er wordt in deze studie niet uitgebreid ingegaan op de inhoud van het werk van een klinisch psycholoog. Voor een uitgebreid verslag daarvan wordt 
verwezen naar het reeds genoemde rapport van de NRV. Volgens dit rapport werd klinische psychologie aanvankelijk alleen bedreven in de klinische psychiatrie. Klinische psychologen oriënteerden zich primair op de diagnostiek en de behandeling van afwijkend gedrag. In de vijftiger jaren deed de klinische psychologie zijn intrede in de gezondheidszorg. Sedertdien trad de klinisch psycholoog ook in andere settingen op, zoals in medische kleuterdagverblijven en medische kindertehuizen, de verpleeghuiszorg, de revalidatie-voorzieningen, de eerstelijns-gezondheidszorg en de geestelijke gezondheidszorg. In veel gevallen werken klinisch psychologen samen met artsen, dat wil zeggen met de huisarts in de eerstelijn en met de medisch specialist in het ziekenhuis. Vooral in de jaren zestig en zeventig kreeg de $k$ linische psychologie vaste voet aan de grond in de medische zorg, door het tot stand komen van de afdelingen voor medische psychologie in de academische ziekenhuizen. Deze aandacht voor de psychische en sociale aspecten van ziekte en ziekenhuisverblijf is de laatste decennia nog verder toegenomen. Volgens het eerder genoemde rapport van de NRV bestaat de functie van de klinisch psycholoog op dit moment in elk geval uit een patiëntgebonden functie met diagnostiek en therapie als hoofdtaken. Daarnaast kan volgens sommige visies de functie van de klinisch psycholoog ook taken omvatten als consulent, begeleider van personeel, en als intern beleidsadviseur.

In het verleden is al vaker onderzoek gedaan naar de arbeidsmarktpositie en arbeidsmarktvooruitzichten van (klinisch) psychologen. Vaak wordt in deze onderzoeken echter alleen het aanbod van psychologen of alleen de vraag naar psychologen onderzocht. Ook is een deel van deze onderzoeken slechts gericht op één bepaalde faculteit of van een erg geringe steekproefomvang. Voorbeelden van dit soort studies met een beperkte omvang zijn de enquêtes onder de afgestudeerden van afzonderlijke universiteiten door Kerkhof en Engels (1986), Dijkstra en Bannenberg (1986), Schaufeli en De Vries (1987), Mensen en Van den Burgh (1989) en Van Giels (1989) en het uitgevoerde advertentieonderzoek van De Ruyter (1988). Daarbij is vermeldenswaard dat in het onderzoek van Schaufeli en De Vries een vergelijking wordt gemaakt met enquêteresultaten van andere faculteiten. Ook Mensen en Van den Burgh maken een vergelijking tussen verschillende faculteiten, maar in hun studie worden gegevens gebruikt van de studierichting psychologie als geheel zonder een nadere opsplitsing naar afstudeerrichting. Een ander onderzoek waarin gegevens voor meerdere faculteiten tegelijk worden gecombineerd is Is er toekomst voor psychologen? (Holzer, 1984). Deze studie maakt gebruik van de NIP-ledenlijst en gegevens van werkzoekenden. De in dit onderzoek geformu- 
leerde conclusie luidt 'Wat betreft de werkloosheid onder psychologen moet van een rampzalige ontwikkeling worden gesproken: vooral in de laatste jaren is dit aantal schrikbarend gestegen, terwijl het einde nog niet in zicht 1ijkt'. De gegevens van de afgestudeerden werden in 1985 bijgesteld met de nieuwste gegevens van de faculteiten en opnieuw gepubliceerd. Daarbij bleek de arbeidsmarktsituatie niet gewijzigd.

Een studie die veel breder is opgezet dan de voorgaande onderzoeken betreft het rapport Toekomstige ontwikkelingen op de arbeidsmarkt voor psychologen (Krijnen en Van den Berg, 1976). Dit rapport bevat prognoses van de arbeidsmarkt voor klinisch psychologen op basis van een analyse van kwantitatieve gegevens aangevuld met een Delphi-onderzoek. De prognoses in dit onderzoek zijn inmiddels danig achterhaald. In deze studie werd enerzijds verwacht dat het aanbod van afstuderende psychologen vanaf 1980 zou gaan dalen terwijl het aanbod in werkelijkheid alleen maar verder gestegen is. Anderzijds werd de ontwikkeling van de vraag naar psychologen te positief ingeschat, zodat de totale situatie zich veel minder gunstig heeft ontwikkeld dan werd verwacht.

Om inzicht te krijgen in de arbeidsmarktperspectieven voor (klinisch) psychologen is het noodzakelijk nieuwe prognoses op te stellen voor het aanbod van en de vraag naar klinisch psychologen. In hoofdstuk 2 van dit rapport wordt de methode waarmee de prognoses van het huidige onderzoek zijn samengesteld nader toegelicht. In hoofdstuk 3 wordt het aanbod van klinisch psychologen behandeld en in hoofdstuk 4 wordt de relevante werkgelegenheid voor klinisch psychologen sectorgewijs besproken. In hoofdstuk 5 wordt verslag gedaan van de resultaten van de interviews die met een aantal deskundigen zijn gehouden over de perspectieven in de verschillende sectoren waarin klinisch psychologen werkzaam zijn. Deze resultaten zijn gebruikt om een voorlopige prognose, die aan de deskundigen werd voorgelegd, bij te stellen. In hoofdstuk 6 wordt ingegaan op de gevoeligheid van de gemaakte prognoses voor alternatieve veronderstellingen en volgt de confrontatie van vraag en aanbod bij twee prognosevarianten. Tenslotte worden enkele conclusies getrokken. 
2. BESCHRIJVING VAN DE METHODE

\subsection{Afbakening onderzoeksgroep en prognoseperiode}

Allereerst moet worden gepreciseerd welke operationele omschrijving van klinisch psycholoog in dit rapport wordt gebruikt. Met klinisch psycholoog wordt hier, in aansluiting op het gestelde in hoofdstuk 1, elke psycholoog bedoeld die als zodanig in de individuele gezondheidszorg werkzaam is. Dit betekent dat voor de afbakening van de te onderzoeken groep psychologen primair wordt gekeken naar de sector waarin men werkzaam is en niet naar de afstudeerrichting van de desbetreffende psycholoog. Dit geldt hoofdzakelijk voor de bepaling van de op dit moment werkzame klinisch psychologen en voor de prognose van de toekomstige behoefte. Bij de bepaling van het toekomstige aanbod van $k l i n i s c h e$ psychologen wordt daarentegen wel rekening gehouden met de gevolgde specifieke afstudeerrichting cq. afstudeerpakket.

Het laatste tijdstip waarop alle totaalcijfers van het Centraal Bureau voor de Statistiek (CBS) over het aantal werkenden in de gezondheidszorg beschikbaar zijn is 31-12-1988. Er zijn per 31-12-1989 wel al een aantal andere gegevens beschikbaar. Omdat van deze gegevens kan worden gebruik gemaakt bij het opstellen van de prognose, wordt in eerste instantie een vijfjarige prognose opgesteld voor de periode 1-1-1990 - 1-1-1995. In tweede instantie zal in hoofdstuk 6 de prognose worden omgerekend tot de periode 1 1-1990 - 31-12-19951.

In dit hoofdstuk wordt ingegaan op de beschikbare databronnen (paragraaf 2.2) en - daarmee samenhangend - de te volgen werkwijze bij de op te stellen prognose (paragrafen 2.3 en 2.4). Aan het einde van dit hoofdstuk wordt in figuur I een grafische weergave gegeven van deze werkwijze. De nummers in dit figuur verwijzen naar de paragraaf van dit rapport waarin het desbetreffende onderdeel wordt behandeld.

\subsection{Overzicht van beschikbare databronnen}

Voor het uitvoeren van dit onderzoek vormt de gebrekkige en onvolledige informatie over de werkgelegenheid van klinisch psychologen het voornaamste knelpunt. De belangrijkste databronnen zijn twee bestanden, die elk slechts

1. Dit is dus een periode van zes jaar. 
een deel van de gegevens over werkzame klinisch psychologen bevatten.

Het CBS verstrekt gegevens over het aantal werkzame personen en het arbeidsvolume in de gezondheidszorg, opgesplitst naar werkvelden als algemene ziekenhuizen, verpleeghuizen e.d. Deze gegevens zijn echter niet beschikbaar voor de groep (klinisch) psychologen. Deze groep valt in de meeste gevallen onder de bredere categorie Medisch en Sociaal-Wetenschappelijke Staf of de categorie Overige Academici.

Een ander belangrijk deel van de gegevens is te ontlenen aan het ledenbestand van het NIP. Dit bestand bevat echter alleen gegevens van psychologen die lid zijn van het NIP en dus niet van alle psychologen in de desbetreffende sectoren. Volgens opgave van het NIP is in de onderzochte werkvelden ongeveer $75 \%$ van de werkzame psychologen lid van het NIP. Van de psychologen in het NIP-ledenbestand zijn nadere gegevens bekend over $0 . a$. leeftijd, geslacht en de werkduur per week ${ }^{2}$.

Omdat beide gegevensbestanden niet op elkaar aansluiten, is het erg lastig om de gegevens op elkaar af te stemmen. In de meeste gevallen is dit opgelost door te veronderstellen dat de psychologen in het NIP-ledenbestand per sector een representatieve steekproef vormen uit de populatie van die sector. Wel is steeds gezocht naar andere databronnen voor nadere informatie over de werkzame psychologen per sector. Deze bronnen zijn helaas voor slechts enkele sectoren of categorieën instellingen aanwezig. Er is geprobeerd om een werkwijze te volgen waarbij zo goed mogelijk rekening wordt gehouden met deze beperkte aanwezigheid van gegevens over de werkgelegenheid van klinisch psychologen.

\subsection{Bepaling van het toekomstig aanbod van klinisch psychologen}

Allereerst wordt het verwachte aanbod van klinisch psychologen in de periode 1990-1995 bepaald. Een belangrijk deel van dit aanbod zal worden gevormd door de uitstroom uit het universitair onderwijs. Van belang is daarom het aantal studenten dat in de periode 1990-1995 uit het universitair onderwijs zal stromen en zal afstuderen in een van de richtingen die opleiden tot klinisch psycholoog. Voor een lijst van klinische richtingen binnen de psychologie wordt verwezen naar bijlage 2. Er wordt met nadruk

2. Zie bijlage 1 voor een overzicht van de gegevens in het NIP-ledenbestand. 
opgemerkt dat deze lijst veel meer richtingen omvat dan alleen de studie-

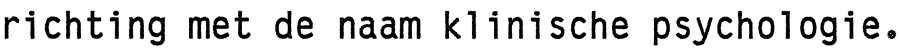

Voor een gedeelte zal de toekomstige uitstroom bestaan uit studenten die reeds op dit moment bezig zijn met hun studie. Op basis van gegevens uit voorgaande jaren wordt een verdeling bepaald van de tijdsduur waarna de huidige studenten zullen afstuderen. Hiervoor worden zogenaamde 'verdeelsleutels' gebruikt, zoals deze staan vermeld in WORSA '89. De precieze wijze van berekening staat beschreven in hoofdstuk 3. Deze berekening levert een prognose op van het aantal in de komende jaren afstuderende psychologen. Omdat niet alle afstudeerrichtingen binnen de psychologie voor dit onderzoek relevant zijn, moet het aandeel van de afstudeerders in een klinische richting worden bepaald. Met behulp van gegevens van de faculteiten over het aantal afstudeerders in de afgelopen jaren kan het aandeel van de klinische richtingen in die jaren worden vastgesteld. Als er vanuit wordt gegaan dat dit aandeel in de prognoseperiode hetzelfde blijft, kan ook het aantal afstudeerders in de klinische richtingen voor de komende jaren worden bepaald.

Het aanbod van klinisch psychologen zal waarschijnlijk niet alleen bestaan uit nieuwe afstudeerders. Ook de studenten die reeds eerder op de arbeidsmarkt kwamen en nog een baan als klinisch psycholoog zoeken, vormen een deel van het aanbod. Deze component van het aanbod zal deels zijn terug te vinden in de werkzoekendenbestanden van de arbeidsbureaus. Waarschijnlijk zullen echter niet alle werkloze klinisch psychologen die hier staan ingeschreven tot het aanbod horen, omdat deze bestanden nogal eens verouderde ('vervuilde') gegevens bevatten. Anderzijds zal een gedeelte van het aanbod van klinisch psychologen waarschijnlijk niet zijn terug te vinden in de bestanden van de arbeidsbureaus. Dit betreft dan bijvoorbeeld de psychologen die reeds een gedeeltelijke werkkring hebben en hun aantal uren als klinisch psycholoog willen uitbreiden, de psychologen die tijdelijk in een andere sector werkzaam zijn en toch als klinisch psycholoog willen werken of de psychologen die opnieuw aan het arbeidsproces willen deelnemen. Bij de laatste groep horen vooral de (herintredende) vrouwen die zich na hun huwelijk van de arbeidsmarkt hebben teruggetrokken, maar in een later stadium opnieuw willen deelnemen.

\subsection{Bepaling van de toekomstige vraag naar klinisch psychologen}

Voor de bepaling van de toekomstige vraag naar $k l i n i s c h$ psychologen wordt 
eerst het huidige arbeidsvolume van klinisch psychologen opgesplitst naar de verschillende sectoren. Vervolgens wordt voor elke sector apart nagegaan of deze sector behoort tot de belangrijke sectoren voor klinisch psychologen, of dat deze sector behoort tot de zogenaamde 'uitwijk'-sectoren. Het kenmerk van deze uitwijksectoren is dat een klinisch psycholoog er niet binnen zijn of haar vakgebied werkzaam is. De klinisch psycholoog werkt hier, eventueel in afwachting van een klinisch functie, in een baan waarvoor geen opleiding tot klinisch psycholoog is vereist. Hierna wordt voor elke sector waarin klinisch psychologen werkzaam zijn de toekomstige groei van het arbeidsvolume van klinisch psychologen bepaald met behulp van reeds aanwezige planningsrapporten en andere prognosegegevens.

Een andere component van de vraag naar klinisch psychologen bestaat uit de vervangingsvraag. Vervangingsvraag treedt op bij uittreding uit het arbeidsproces wegens pensionering, ziekte, overlijden of vertrek naar een andere sector. Bij het bepalen van de toekomstige vervangingsvraag wordt zoveel mogelijk rekening gehouden met de bestaande leeftijdsstructuur en samenstelling naar geslacht van de klinisch psychologen in een bepaalde sector.

De vraag naar klinisch psychologen in de periode 1990-1995 per sector wordt berekend als de som van de toename van het arbeidsvolume in de periode 19901995 en de vervangingsvraag. Sommatie van deze vraag over alle sectoren levert een prognose op van de totale vraag naar nieuwe klinisch psychologen in de periode 1990-1995.

Deze berekeningswijze houdt geen rekening met de vacatures die worden opgevuld door klinisch psychologen die op dit moment al een klinische baan hebben. Dit deel van de vacatures is echter niet van belang voor de totale vraag naar nieuwe klinische psychologen, omdat zij na vervulling leiden tot nieuwe vacatures elders.

Voor een samenvattend overzicht van de te volgen werkwijze bij de arbeidsmarktprognoses voor de klinisch psychologen wordt verwezen naar figuur I. In dit figuur staat vermeld in welke paragrafen van dit rapport de diverse onderdelen van de prognose worden behandeld. 
Figuur I: Prognoseschema van de *arbeidsmarktperspectieven voor klinisch psychologen ${ }^{*}$

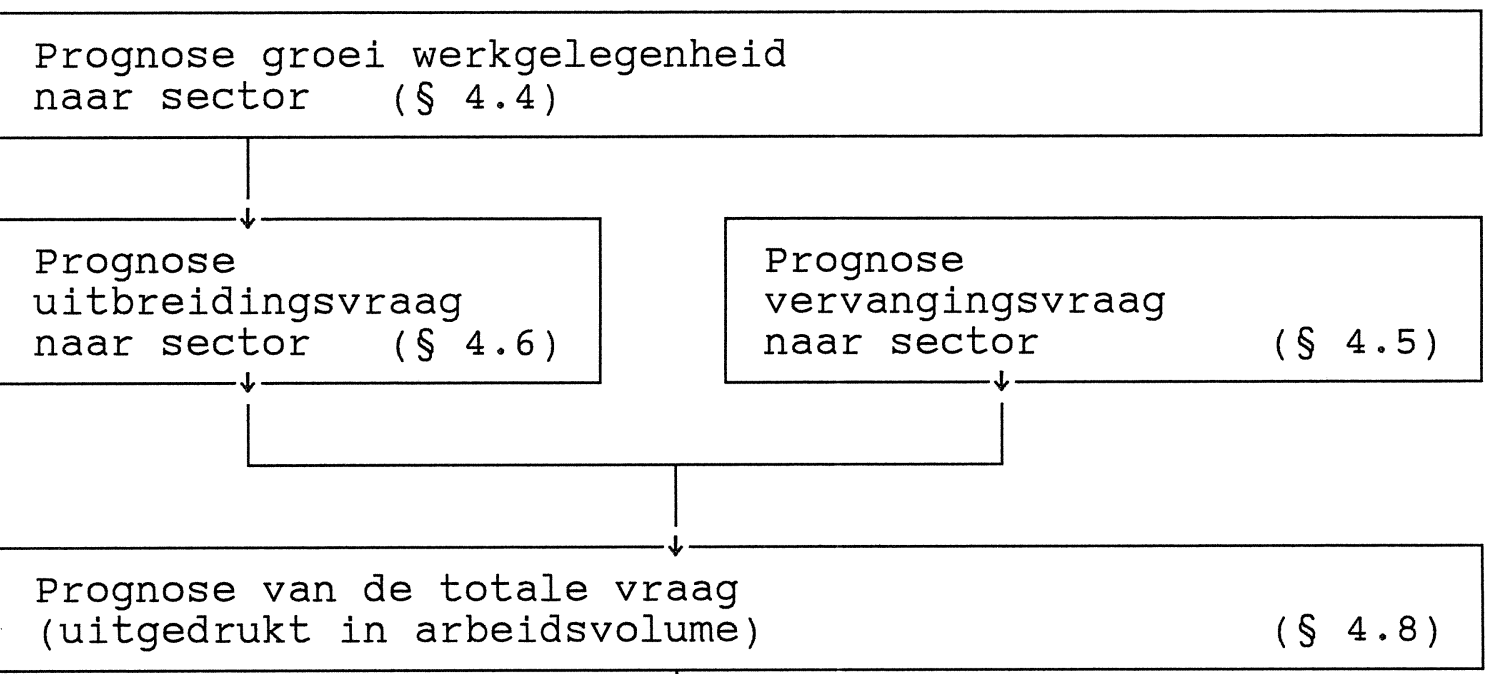

Veronderstellingen

m.b.t. ontwikkeling

arbeidsduurverkorting

en deeltijdarbeid

$(\S 4.7)$

Prognose van de totale vraag

(uitgedrukt in werkzame personen)

versus

Prognose van het totale aanbod

(uitgedrukt in werkzame personen)

$(\$ 6.2)$

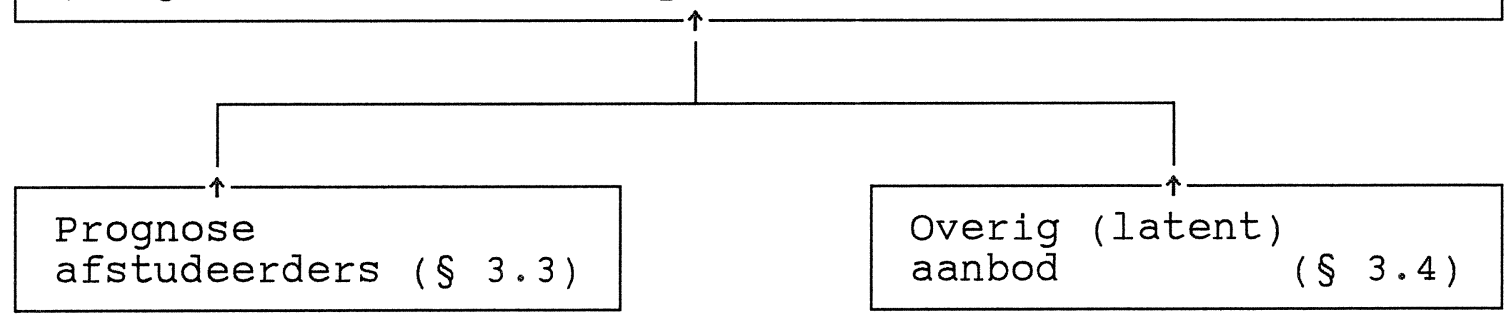

* De cijfers in het schema verwijzen naar de desbetreffende paragrafen.

Bron: ROA 


\section{AANBOD VAN KLINISCH PSYCHOLOGEN}

\subsection{Inleiding}

In dit hoofdstuk wordt geprobeerd een zo volledig mogelijk beeld te vormen van de componenten van het toekomstige potentiële aanbod van klinisch psychologen. Dit aanbod wordt enerzijds gevormd door studenten die op dit moment bezig zijn met hun studie of daar binnenkort aan beginnen en anderzijds door psychologen die in het verleden zijn afgestudeerd en nog op zoek zijn naar een baan als klinisch psycholoog. De eerste component - de uitstroom uit de universiteiten - wordt behandeld in paragrafen 3.2 en 3.3 en de tweede component - de werkzoekende psychologen - komt aan bod in paragraaf 3.4. In paragraaf 3.5 wordt een prognose gemaakt van het totale aanbod van klinisch psychologen voor de periode 1990 - 1995.

\subsection{Uitstroom uit de universiteiten}

Voor de Nederlandse universiteiten wordt jaarlijks door de Taakgroep Studentenramingen (WORSA, 1989), in opdracht van de Minister van Onderwijs en Wetenschappen, een prognose gemaakt van de studentenaantallen. De taakgroep geeft de verwachte aantallen eerstejaars, ingeschrevenen en afstudeerders, uitgesplitst naar studierichting, geslacht en universitaire instelling. In de WORSA 89 -publikatie staat een prognose van het aantal afstuderende psychologen per instelling voor de jaren 1989 t/m 1993. Voor de periode na 1993 wordt in de WORSA-publikatie geen jaarlijkse prognose vermeld, maar slechts een vijfjaarlijkse prognose. Hieronder volgt eerst een korte beschrijving van de wijze waarop de WORSA-prognose tot stand komt.

In de WORSA-publikatie worden rendementscijfers berekend op basis van CBSgegevens over de (cohorten) eerstejaars van 1982/1983 en 1983/1984. WORSA gebruikt het gemiddelde propedeuse-rendement van de cohorten 1982/1983 en $1983 / 1984$ als basis voor het propedeuse-rendement van alle daaropvolgende cohorten. Het berekende propedeuserendement bedraagt $76 \%$. Het verwachte doctoraalrendement wordt vervolgens door het ROA gesteld op $80 \% 3$ van het

3. In de WORSA-publicatie wordt het doctoraalrendement op $90 \%$ gesteld, maar uit de diverse onderwijsverslagen van de psychologische faculteiten van de verschillende universiteiten blijkt dat dit waarschijnlijk te optimistisch is. Een rendement van $80 \%$ geeft een betere benadering van de werkelijkheid. 
propedeuse-rendement. Op deze manier valt het totale rendement van psychologie te becijferen op $80 \% * 0,76=61 \%$. Dit percentage wordt met een vaste sleute 4 verdeeld over de opeenvolgende afstudeerjaren. Dit levert vervolgens de afstudeercoëfficiënten op. Op basis van deze afstudeercoëfficiënten en de prognose van het aantal eerstejaars uit het WORSA-rapport, wordt door het ROA een prognose gemaakt van het aantal afstudeerders voor de jaren 1989 tot en met 1995.

Omdat de studierichting Geestelijke Gezondheidkunde (GGK) van de Faculteit der Gezondheidswetenschappen aan de Rijksuniversiteit Limburg wellicht ook als vooropleiding tot $k l i n i s c h$ psycholoog kan gelden 5 , wordt deze meegenomen bij de bepaling van het toekomstige aanbod van klinisch psychologen. Op dezelfde manier als bij psychologie wordt het doctoraalrendement van gezondheidswetenschappen vastgesteld op $84 \% * 0,94=79 \%$. Dit percentage wordt ook met een vaste sleute ${ }^{6}$ verdeeld over de prognosejaren. De rest van de prognose verloopt analoog aan de prognose van het aantal afstudeerders van de studierichting psychologie.

\subsection{Prognose van het aantal afstudeerders 1990-1995}

De prognoses van het aantal afstuderende psychologen en klinisch psychologen, zoals deze op basis van de WORSA-publicatie en de berekeningen zoals die beschreven zijn in paragraaf 3.2 zijn gemaakt, worden weergegeven in tabel $1^{7}$. Een grafische weergave van deze aantallen staat in figuur II.

Bij deze prognose wordt uitgegaan van een vast aandeel van de klinische richtingen in het totaal aantal afstuderende psychologen per faculteit. Daarbij wordt gebruik gemaakt van recente gegevens over het aandeel van de klinische richtingen, zoals deze zijn opgegeven door de verschillende faculteiten en aangevuld met gegevens van Holzer (1984).

4. Zie bijlage 3

5. Hierover is overleg gaande tussen het NIP en de Faculteit der Gezondheidswetenschappen.

6. Zie bijlage 3

7. Zie bijlage 3 voor gegevens uit vroegere jaren. 
Tabel 1. Prognose van het aantal afstudeerders, 1989-1995

\begin{tabular}{|c|c|c|c|}
\hline Jaar & totaal psychologie & klinische richting* & $\begin{array}{c}\text { klinische richting } \\
\text { inclusief GGK }\end{array}$ \\
\hline 1989 & 906 & 608 & 627 \\
\hline 1990 & 974 & 645 & 668 \\
\hline 1991 & 1009 & 657 & 692 \\
\hline 1992 & 1046 & 681 & 724 \\
\hline 1993 & 1019 & 662 & 706 \\
\hline 1994 & 1026 & 663 & 708 \\
\hline 1995 & 1027 & 663 & 707 \\
\hline
\end{tabular}

* Overeenkomstig de afbakening uit bijlage 2 .

Bron: ROA/WORSA

Figuur II

Afstuderende $k$ I inisch psychologen

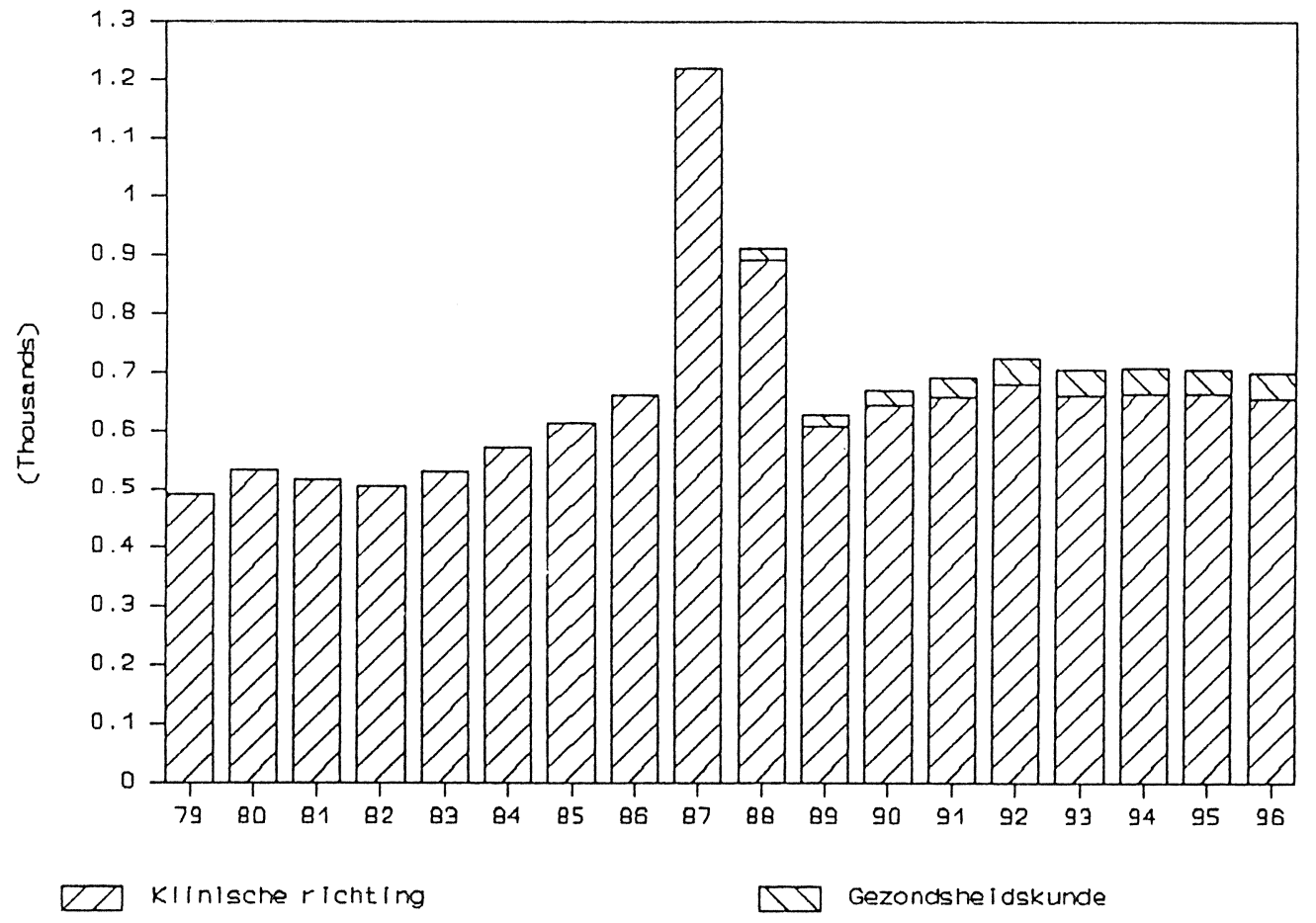

Uit tabel 1 blijkt dat in de toekomst het aantal afstudeerders psychologie tamelijk constant blijft. Mede als gevolg van de gemaakte aannamen blijft dan ook het aantal afstudeerders in de klinische richtingen (inclusief GGK) tamelijk constant en wel ongeveer 700 personen per jaar. Let wel dat het hier, zoals reeds eerder werd opgemerkt, meer afstudeerrichtingen betreft 
dan alleen de richtingen die de naam klinische psychologie dragen (zie voor een overzicht bijlage 2).

Bovenstaande prognoses blijken erg ongevoelig voor toekomstige veranderingen in het aantal eerstejaars, vanwege de vertraging waarmee zij afstuderen. Een structurele daling van het aantal eerstejaars vanaf het studiejaar 1991/1992 heeft pas in het studiejaar 1994/1995 een kleiner aantal afstudeerders tot gevolg. Bij doorrekening van de prognose blijkt een structurele daling van het aantal eerstejaars met bijvoorbeeld $10 \%$ slechts een 40 -tal afstudeerders (ca. $1 \%$ van de afstudeerders in de periode 1990-1995) minder tot gevolg te hebben.

De prognose is echter wel gevoelig voor fouten in het bepalen van de aandelen van de diverse afstudeerrichtingen, omdat deze direct tot veranderingen in de desbetreffende aantallen afstudeerders kunnen leiden. Een structurele verschuiving van het aandeel van de klinisch richtingen van bijvoorbeeld $10 \%$ leidt tot een verschil van $10 \%$ in het totaal aantal afstudeerders. Dit is een erg grote verschuiving. In de praktijk zullen de verschuivingen per faculteit op zijn minst gedeeltelijk tegen elkaar wegvallen en zal het uiteindelijke total in dit gegeven voorbeeld toch minder dan $10 \%$ kunnen afwijken.

\subsection{Arbeidsaanbod van werkzoekende klinisch psychologen}

Tot het aanbod van klinisch psychologen op de arbeidsmarkt behoren niet alleen de toekomstige afstudeerders in de klinische psychologie, maar ook de afstudeerders uit het verleden die nog geen baan in een klinische richting hebben gevonden, maar dit wel ambiëren (of die nog meer uren per week zouden willen werken). Daarom worden ook de bestanden van werkzoekenden nader onderzocht om dit extra aanbod te kunnen bepalen.

De werkloosheid onder psychologen blijkt de laatste jaren gestaag te stijgen (Wenno, 1987; Tupan-Wenno, 1988). Het aantal werkloze psychologen in de maand november bedraagt in de jaren 1985 tot en met 1988 respectievelijk 1801, 1818, 1788 en 2281 personen. In augustus 1989 waren dit er 2359, waarvan er 1172 langer dan één jaar staan ingeschreven (Coppens en TupanWenno, 1989). Deze cijfers van het Ministerie van Onderwijs en Wetenschappen zijn helaas niet verder uitgesplitst naar richtingen, zodat hieruit de ontwikkeling van de werkloosheid van klinisch psychologen binnen de 
studiesector psychologie niet nader bepaald kan worden.

Het ROA beschikt over gedetailleerde werkzoekendengegevens van het Ministerie van Sociale Zaken en Werkgelegenheid voor drie tijdstippen (namelijk 15 april 1987, 15 april 1989 en 15 april 1990). Deze gegevens omvatten ook gedetailleerde informatie van de ingeschreven klinisch psychologen. Deze informatie omvat onder andere het hoofdberoep, het laatste beroep en de SBI-code 8 van het bedrijf waarbinnen men het laatste beroep uitoefende. De meeste werklozen in deze bestanden zijn overigens pas afgestudeerden, die nog geen baan hebben gehad. Daarom zal in de meeste gevallen geen laatste beroep of SBI-code bekend zijn. Een overzicht van de gegevens uit deze bestanden voor de richtingen die het beste aansluiten bij de in dit rapport gebruikte definitie van klinisch psycholoog wordt gepresenteerd in bijlage 4. De geselecteerde richtingen zijn klinische psychologie, persoonlijkheidsleer, psychodiagnostiek, ontwikkelingspsychologie, kinder- en jeugdpsychologie, psychogerontologie.

De meest opvallende verschuivingen in deze gegevens tussen 1987 en 1989 betreffen vooral het grotere aantal ingeschrevenen en het gestegen percentage vrouwen. De verschuivingen in de sectoren waarin het laatste beroep werd vervuld zijn allemal erg klein, zodat daar geen conclusies uit mogen worden getrokken. Het is opmerkelijk dat het grote aanbod van afgestudeerde psychologen in de jaren 1987 en 1988 niet tot uitdrukking komt in een evenredige stijging van het aantal werklozen. Wellicht slagen de pas afgestudeerden van recente jaren er beter in een plaats op de arbeidsmarkt te vinden dan diegenen die al langer staan ingeschreven of schrijven zij zich niet in bij een arbeidsbureau (bijvoorbeeld vanwege een verdienende partner).

\subsection{Het totale arbeidsaanbod van klinisch psychologen}

Naast de uitstroom van psychologen uit de universiteiten en de psychologen die als werkzoekende staan ingeschreven, bestaat het potentiële aanbod uit nog meer - verborgen - componenten. Enerzijds zijn er de psychologen die geen baan hebben, maar niet als werkzoekend staan ingeschreven. Dit betreft bijvoorbeeld vrouwen die zich tijdelijk van de arbeidsmarkt hebben terugge-

8. De SBI-code is de indeling volgens de Standaard Bedrijfsindeling (1982) van het CBS. 
trokken om hun gezin te verzorgen. Deze vrouwen kunnen zich eventueel in een later stadium weer opnieuw op de arbeidsmarkt aanbieden. Over de omvang van deze groep zijn echter geen nadere gegevens bekend, zodat deze component noodgedwongen wordt verwaarloosd. Anderzijds zijn er ook nog de psychologen die reeds als zodanig werkzaam zijn, maar nog meer uren per week willen werken. Deze component is moeilijk afzonderlijk te bepalen zodat deze als onderdeel van de gemiddelde arbeidsduur per week voor psychologen wordt beschouwd.

In het vervolg wordt $50 \%{ }^{9}$ van de 1664 werkzoekenden zonder baan (per 15 april 1990) tot het arbeidsaanbod gerekend, ondermeer omdat een aantal werklozen wegens langdurige werkloosheid waarschijnlijk niet meer voldoet aan de eisen die aan klinisch psychologen worden gesteld of niet langer een baan als klinisch psycholoog ambieert.

Het totale potentiële aanbod van klinisch psychologen wordt gevormd door de som van het aantal afstudeerders in de verschillende klinische richtingen (inclusief GGK) en de helft van de bij de arbeidsbureaus als 'werkzoekend zonder baan' ingeschreven psychologen. In de periode 1990-1995 zullen naar verwachting ongeveer $4100 \mathrm{klinisch}$ psychologen afstuderen (zie tabe 1 1). Het aantal werkloze klinisch psychologen dat tot het aanbod kan worden gerekend bedraagt ongeveer 800 . Volgens deze prognoses zullen in de periode 1990-1995 zich dus ongeveer 4900 nieuwe klinisch psychologen kunnen gaan aanbieden op de arbeidsmarkt.

9. Uit enkele enquêtes (Kerkhof en Engels, 1986; Schaufe1i, 1987), gehouden onder afgestudeerde psychologen, blijkt ongeveer $50 \%$ van de bij het arbeidsbureau ingeschreven psychologen daadwerkelijk op zoek te zijn naar een baan als klinisch psycholoog. 


\section{VRAAG NAAR KLINISCH PSYCHOLOGEN}

\subsection{Inleiding}

In dit hoofdstuk wordt de werkgelegenheidsontwikkeling van klinisch psychologen behandeld. Alle sectoren die een substantieel deel van deze werkgelegenheid vormen, worden eerst kort besproken. Hierbij wordt de nadruk gelegd op de beschikbaarheid van kwantitatieve werkgelegenheidsgegevens. Aan allerlei mogelijke kwalitatieve ontwikkelingen wordt op dit moment voorbij gegaan. In paragraaf 4.2 worden de relevante sectoren geselecteerd en in paragraaf 4.3 besproken. In paragraaf 4.4 worden toekomstramingen die betrekking hebben op de werkgelegenheid in deze sectoren geïnventariseerd en beschreven. In paragraaf 4.5 wordt aandacht besteed aan de vervangingsvraag naar klinisch psychologen. In paragraaf 4.6 wordt de totale vraag naar klinisch psychologen in de komende periode gepresenteerd. Paragraaf 4.7 van dit hoofdstuk gaat in op de vraag welke gevolgen arbeidsduurverkorting en veranderingen in de mate van deeltijdarbeid kunnen hebben op de werkgelegenheid van klinisch psychologen. Vervolgens wordt in paragraaf 4.8 op basis van de genoemde elementen uit dit hoofdstuk een voorlopige prognose samengesteld.

\subsection{Bepaling van relevante sectoren}

Om alle werkgelegenheidsgegevens met elkaar te kunnen vergelijken, zijn deze gegevens uitgedrukt in arbeidsjaren. Een arbeidsjaar is de werkgelegenheid van één werknemer die het voor de desbetreffende sector normale full-time aantal uren per week werkt. Dit normale aantal uren is voor een sector vaak vastgelegd in een Collectieve Arbeidsovereenkomst. Het gebruik van de eenheid arbeidsjaar betekent dat het voor onze analyse niet uitmaakt of een arbeidsplaats op dit moment bezet wordt door één psycholoog die 36 uur per week werkt of door twee psychologen die elk 18 uur per week werken. Het voordeel van het gebruik van deze eenheid is dat bij de uit te voeren berekeningen pas in laatste instantie rekening hoeft te worden gehouden met het gemiddelde aantal personen per arbeidsjaar (de zogenaamde P/A-ratio) om tot een prognose in werkzame personen te komen.

Om te bepalen welke sectoren relevant zijn voor de werkgelegenheid van klinisch psychologen is het NIP-ledenbestand geraadpleegd (zie voor een overzicht van de gegevens bijlage 1 ). Hierbij wordt verondersteld dat in 
alle relevante sectoren wel enkele NIP-leden werkzaam zijn. Omdat in het algemeen echter niet alle psychologen in een sector lid zijn van het NIP, worden voor het vaststellen van het totaal aantal werkenden in een sector andere databronnen gebruikt, zoals gegevens van het CBS en van het Nationaal Ziekenhuis Instituut (NZI).

Om na te gaan welke sectoren voor klinisch psychologen belangrijk zijn, ligt het voor de hand de klinische richtingen uit het totale NIP-ledenbestand te selecteren. Daarvoor kunnen de richtingen worden gebruikt die in deze studie als klinisch zijn bestempeld (zie bijlage 2). Het probleem doet zich dan voor dat een aantal psychologen met een niet-klinische richting toch is geregistreerd bij het NIP als klinisch psycholoog en ook werkzaam is binnen de gezondheidszorg, bijvoorbeeld bij een RIAGG. Bij het bepalen van de relevante sectoren voor klinisch psychologen wordt daarom niet geselecteerd op klinische afstudeerrichtingen, maar worden de gegevens van alle NIPpsychologen gebruikt. Een nadeel hiervan is wel dat er ook sectoren worden gevonden die voor dit onderzoek niet relevant zijn. Er worden nu namelijk ook verschillende sectoren gevonden waar geen psychologen met een klinische afstudeerrichting werken. Deze sectoren blijken dan verderop in het rapport volgens de CBS-cijfers geen werkgelegenheid specifiek voor klinisch psychologen op te leveren, zodat het weglaten van een selectiecriterium uiteindelijk geen rol voor de resultaten zal spelen. De resultaten van de gevonden verdeling van de werkgelegenheid van NIP-leden naar sector is in tabe 12 weergegeven.

Wanneer de gegevens uit tabel 2 worden gecombineerd met de andere databestanden van de verschillende sectoren, dan blijkt dat voor ca. $51 \%$ van de werkgelegenheid van NIP-psychologen gegevens beschikbaar zijn over het totaal aantal werkzame psychologen in de desbetreffende sector. Nog eens $27 \%$ van de werkgelegenheid uit deze tabel behoort tot het onderwijs en de overige uitwijksectoren. Voor deze sectoren is helaas niet bekend hoeveel psychologen er in totaal werkzaam zijn. Er blijft dan nog $22 \%$ van de werkgelegenheid over waarover in het geheel geen cijfers uit andere bronnen beschikbaar zijn. Vermoedelijk komt deze werkgelegenheid voor een groot deel voor rekening van psychologen met een niet-klinische richting, zoals Arbeids- en organisatiepsychologie, historische psychologie e.d. 
Tabel 2. De verdeling van NIP-leden naar sector, 1989 (gewogen naar arbeidsvolume)

\begin{tabular}{|c|c|}
\hline Sector & Percentage \\
\hline Maatschappelijke dienstverlening & 34,8 \\
\hline w.v. Kindertehuizen & 1,2 \\
\hline RIAGG & 14,9 \\
\hline$C A D$ & 0,7 \\
\hline Psychotherapeutenpraktijken & 2,7 \\
\hline Praktijken van eerstelijns psychologen & 3,2 \\
\hline Overige zelfstandig gevestigde psychologen & 3,8 \\
\hline School- en beroepskeuze ${ }^{\star}$ & 1,4 \\
\hline Schoolbegeleidingsdiensten * & 3,5 \\
\hline Overig & 3,4 \\
\hline Intramurale Gezondheidszorg & 33,4 \\
\hline w.v. Ziekenhuizen & 13,6 \\
\hline Psychiatrische ziekenhuizen & 11,7 \\
\hline Overig & 8,1 \\
\hline Onderwijs & 13,9 \\
\hline Zakelijke dienstverlening & 8,9 \\
\hline Overige dienstverlening & 4,0 \\
\hline w.v. Reclassering en gevangenissen & 0,9 \\
\hline Overig & 3,1 \\
\hline Overig & 5,0 \\
\hline Totaal & 100,0 \\
\hline
\end{tabular}

* De betreffende sector is volledigheidshalve opgenomen, maar wordt verderop in het rapport niet meer onderscheiden.

Bron: ROA/NIP

Om na te gaan of er sprake is van duidelijke trends in de ontwikkeling van de werkgelegenheid van NIP-leden, worden de sectoren waarin zij werkzaam zijn vergeleken met de sectoren waarin NIP-leden werkzaam zijn die na 1984 zijn afgestudeerd. In de laatste categorie vallen 941 NIP-leden. De belangrijkste sectoren voor recent afgestudeerde NIP-psychologen staan in bijlage 7. Bij het vergelijken van tabel 2 met bijlage 7 blijkt dat de verdeling van de werkgelegenheid van recent afgestudeerden naar sector niet opvallend afwijkt van de verdeling van de totale populatie. Er doet zich bij recent afgestudeerden alleen een verschuiving voor van de sector Maatschappelijke 
dienstverlening naar de sectoren Onderwijs en Zakelijke dienstverlening. Dit wordt waarschijnlijk veroorzaakt door het grotere aandeel van de richting Arbeids \& Organisatiepsychologie onder de recent afgestudeerden. Bijna de helft van de werkgelegenheid in de laatste sector behoort tot de categorie Algemene Consultancy.

\subsection{Werkgelegenheid per sector}

\section{INTRAMURALE GEZONDHEIDSZORG}

Eén van de belangrijkste sectoren voor klinisch psychologen is de intramurale gezondheidszorg. Het gaat hier om ziekenhuizen, verpleeghuizen e.d. Voor de bepaling van de ontwikkeling van het arbeidsvolume binnen de intramurale zorg wordt gebruik gemaakt van CBS-gegevens 10 over het aantal bezette arbeidsplaatsen. Zie voor deze gegevens bijlage 5. Afgezien van enkele kleine verschillen, door de verschillen in de periode waarop de gegevens betrekking hebben, komen de cijfers van het CBS overeen met de cijfers uit het Financieel Overzicht Zorg (Tweede Kamer, 1988) en de NZIcijfers (NZI, 1987). De categorie (klinisch) psychologen wordt gerekend tot de Medisch en Sociaal Wetenschappelijke Staf (categorie 416) en wordt niet afzonderlijk vermeld. De gegevens zijn wel opgesplitst naar Algemene, Academische, Categorale en Psychiatrische Ziekenhuizen, Inrichtingen voor Zwakzinnigen, Verpleeghuizen en de Inrichtingen voor Zintuiglijk Gehandicapten. Verder zijn de Medische Kindertehuizen en de Medische Kleuterdagverblijven opgenomen, hoewel deze sinds kort niet meer tot de gezondheidszorg worden gerekend.

Helaas is slechts op één bepaald tijdstip bekend hoeveel klinisch psychologen er in de intramurale gezondheidszorg werkzaam zijn. Volgens het rapport Klinisch psycholoog in ziekenhuizen en verpleeghuizen betrof het in 1984 159,7 arbeidsplaatsen in de algemene ziekenhuizen en in 1985 45,3 arbeidsplaatsen in verpleeghuizen.

Er is niet altijd precies bekend welke SBI-sectoren onder een bepaalde categorie vallen, omdat door het CBS wordt uitgegaan van erkenning volgens de Algemene wet bijzondere ziektekosten (AWBZ) en niet van de SBI-code. De

10. Deze cijfers hebben betrekking op het aantal bezette arbeidsplaatsen per 31 december voor de jaren $1975 \mathrm{t} / \mathrm{m} 1988$. 
indeling in categorieën door het CBS en onze indeling in sectoren kunnen daarom iets van elkaar afwijken.

\section{EXTRAMURALE ZORG}

Binnen de extramurale zorg is voor de klinisch psycholoog vooral de Ambulante Geestelijke Gezondheidszorg (AGGZ) van belang. Binnen de AGGZ worden de volgende instellingen onderscheiden: Regionale Instellingen voor Ambulante Geestelijke Gezondheidszorg (RIAGG), Consultatiebureaus voor Alcohol en Drugs (CAD) en een tiental overige instellingen.

De beschikbare informatie over de werkgelegenheid bij de RIAGG's bestaat uit uittreksels uit het personeelsinformatiesysteem. Deze informatie beperkt zich tot de instituten die aangesloten zijn bij de Werkgeversvereniging Ambulante Geestelijke Gezondheidszorg (WAGG). Dit betreft 51 van de 58 RIAGG's en een aantal verwante (overigens zeer kleine) instituten. Van psychologen die bij deze instellingen werken zijn, over de periode 19861988 zeer gedetailleerde gegevens beschikbaar met betrekking tot leeftijd, geslacht, aantal gewerkte uren en in- en uitstroom. De gegevens van de WAGG kunnen echter niet gebruikt worden om de groei van het aantal psychologen in deze sector te prognosticeren, omdat het aantal aangesloten instellingen steeds is toegenomen en daarmee automatisch het aantal psychologen.

De beschikbare informatie van het CBS over de CAD's bestaat uit het aantal werkzame personen en het aantal psychologen over de periode 1985 - 1988. Zie hiervoor bijlage 6 .

In het jaar 1980 waren er nog 119 overige instellingen binnen de extramurale zorg. Deze zijn gedurende de laatste jaren toegevoegd aan de RIAGG's, zodat er op dit moment nog maar 10 overige instellingen over zijn. Aangezien daarover geen nadere gegevens beschikbaar zijn en de totale werkgelegenheid in deze instellingen ook zeer gering is, worden deze verder verwaar loosd.

Vanaf 1988 worden in de CBS-statistieken de psychotherapeuten in de extramurale zorg als aparte groep onderscheiden. De psychotherapeuten zaten eerst voor een deel bij de psychologen, zodat het aantal overige academici (waaronder de psychologen) per 1988 lijkt te dalen. Bij het opstellen van een prognose voor deze sector moet hiermee dus rekening gehouden worden. 
EERSTELIJNS PSYCHOLOGEN

Een andere, sterk groeiende sector betreft de praktijken van psychologen in de eerste lijn. Hiervoor wordt de informatie gebruikt van het NIVEL (Van Rooij en Verhaak, 1989). Het betreft hier een enquête onder 825 psychologen die minstens 4 uur per week besteden aan eerstelijnszorg. Van Rooij en Verhaak schatten het totale aantal zelfstandig gevestigde psychologen op 825 à 1260 .

Bovengenoemde steekproef is door Van Rooij en Verhaak gecontroleerd op representativiteit. Het blijkt dat de leeftijdsopbouw, plaats van afstuderen en universiteit van de psychologen in de steekproef conform zijn aan de psychologen in het NIP-ledenbestand. Ongeveer $95 \%$ heeft een opleiding die onder onze definitie van klinische psychologie valt. Voor een kort overzicht van de gegevens uit deze enquête wordt verwezen naar bijlage 8 .

Het is zeer riskant om voor deze sector een prognose van de werkgelegenheid te maken. Uit de enquête blijkt dat de meeste van de huidige praktijken zeer recent zijn. Op basis daarvan kan een flinke groei in de toekomst worden verwacht. Het kan echter ook zo zijn dat de meeste praktijken slechts dienen ter overbrugging van de wachtperiode tussen het afstuderen en de aanvang van een dienstverband (of opvulling van een part-time dienstverband). In dat geval komen er steeds veel praktijken bij maar vallen er ook veel af, zodat het bestand bestaat uit veel recent gestarte praktijken, waarvan de bestaansduur onzeker is. Er zal echter worden verondersteld dat een flink deel van de groei zich nog zal voortzetten in de komende periode.

\section{OVERIGE SECTOREN}

Voor de overige sectoren zijn er niet veel gegevens beschikbaar. Binnen de overige sectoren zijn vooral Onderwijs, Zakelijke Dienstverlening en Openbaar Bestuur van belang. De belangrijkste categorieën die in deze sectoren voorkomen zijn consultancy, personeelsselectie, onderwijs op HBOniveau en onderwijs op Wo-niveau. De werkgelegenheid in deze sectoren is echter waarschijnlijk slechts ten dele gebonden aan de opleiding tot klinisch psycholoog. Daarom worden deze sectoren beschouwd als uitwijksectoren voor klinisch psychologen en verder niet uitgebreid meegenomen in het bepalen van de vraag naar klinisch psychologen. 


\subsection{Overzicht van relevante toekomstramingen}

Voor de belangrijkste sectoren waar klinisch psychologen werkzaam zijn, namelijk de intramurale en de extramurale gezondheidszorg, bestaan de volgende toekomstramingen:

- Financieel Overzicht Zorg 1990, 1989 (en eerdere jaren).

- Over voorzieningengebruik en personeel in de kwartaire sector 19831987, opgesteld door de commissie HARK, 1983.

- Trendrapport kwartaire sector 1983-1990, Sociaal en Cultureel Planbureau (SCP), 1984 .

- Memorandum kwartaire sector 1986-1990, SCP, 1986.

- Trendrapport kwartaire sector 1970-1993, SCP, 1989.

- Vraag naar en aanbod van arbeid in 4 WVC sectoren, Groot en Van Tits, 1989.

De laatste vijf prognosestudies berusten allen op dezelfde methode. Aan de hand van enkele gebruiksindicatoren worden volgens verschillende scenario's toekomstramingen gemaakt. Overigens geeft de meest recente SCP-studie slechts een toekomstraming uitgedrukt in verwachte kosten en niet meer in personee1. De ramingen van het SCP worden verderop in deze paragraaf uitvoeriger besproken.

Verder bestaan er nog enige rapporten met ramingen voor specifieke beroepsgroepen, zoals het NEI-planningsrapport voor verpleegkundigen en de KMGbehoefteplanning voor medisch specialisten.

Sinds enkele jaren geeft het SCP regelmatig een trendrapport met betrekking tot de kwartaire sector uit. De toekomstraming van het Trendrapport kwartaire sector 1983-1990 wordt weergegeven in bijlage 9. Bij vergelijking van deze raming met de gerealiseerde cijfers blijkt dat vooral de basisraming dicht in de buurt van de werkelijke waarden ligt. De raming geeft voor de jaren '83-'84 een overschatting (waarschijnlijk wegens ombuigingen waarmee geen of niet voldoende rekening was gehouden), maar voor de jaren '85-'87 een onderschatting. In 1987 liggen raming en realisatie dicht bij elkaar. De meeste recente toekomstraming van het SCP is die uit het Trendrapport kwartaire sector 1970-1993. Deze staat weergegeven in tabel 3. In de zogenaamde 'demoraming' is, in tegenstelling tot de basisraming, expliciet rekening gehouden met de demografische ontwikkeling van de bevolking in de desbetreffende periode. 
Tabel 3. Ramingen van het voorzieningengebruik, indexcijfers $(1986=100), 1988-1993$

\begin{tabular}{llll}
\hline Sector & 1988 & 1990 & 1993 \\
\hline $\begin{array}{l}\text { Ziekenhuizen } \\
\text { demoraming } \\
\text { basisraming }\end{array}$ & 102 & 104 & 107 \\
$\begin{array}{l}\text { Psychiatrische Ziekenhuizen } \\
\text { demoraming } \\
\text { basisraming }\end{array}$ & 102 & 103 & 105 \\
$\begin{array}{l}\text { Extr. geestelijke gezondheidszorg } \\
\text { demoraming } \\
\text { basisraming }\end{array}$ & 101 & 103 & 104 \\
$\begin{array}{l}\text { Verpleeghuizen } \\
\text { demoraming } \\
\text { basisraming }\end{array}$ & 104 & 108 & 113 \\
$\begin{array}{l}\text { Zwakzinnigeninrichtingen } \\
\text { demoraming } \\
\text { basisraming } \\
\text { Gezinsvervangende tehuizen voor gehandicapten } \\
\text { demoraming } \\
\text { basisraming }\end{array}$ & 103 & 106 & 109 \\
& 114 & 128 & 154 \\
\hline
\end{tabular}

Bron: SCP

Het blijkt dat in het verleden de ontwikkeling van het voorzieningengebruik en de ontwikkeling van de personeelssterkte niet volledig gelijk op zijn gegaan. Toch zullen in dit rapport de (door de het SCP bepaalde) reeksen voor het verwachte voorzieningengebruik worden gebruikt om de toekomstige personeelssterkte te bepalen. Hierbij wordt het groeitempo in de periode 1993 tot 1995 gelijk verondersteld aan het groeitempo in de periode 1990 tot 1993. De groei van de personeelssterkte is bepaald door een regressieanalyse uit te voeren met het indexcijfer van de personeelssterkte op het indexcijfer van het voorzieningengebruik. Daarbij wordt verondersteld dat de personeelssterkte slechts gedeeltelijk afhankelijk is van het gebruik. De prognose in indexcijfers die uit deze werkwijze voortvloeit, wordt gepresenteerd in bijlage 10. Vervolgens zijn de indexcijfers omgezet in een raming van het aantal werkzame psychologen in 1995. Het resultaat daarvan is weergegeven in paragraaf 4.6 .

\subsection{Vervangingsvraag}

Op grond van de verdeling van de werkende $k l i n i s c h$ psychologen naar leeftijd en geslacht per sector kan de vervangingsvraag naar klinisch psychologen per sector worden bepaald. Helaas is de leeftijdsstructuur per sector niet 
bekend voor de hele populatie. De leeftijdsstructuur per sector is echter wel bekend voor NIP-leden. Daarom wordt als benadering verondersteld dat de NIP-leden in elke sector qua leeftijdsstructuur representatief zijn voor de gehele populatie klinisch psychologen in die sector. Het NIP-ledenbestand wordt daartoe voor elke relevante sector in leeftijdsklassen opgedeeld. Zie figuur III voor de verdeling van de NIP-leden naar leeftijd en geslacht.

Figuur III

NIP-leden naar geslacht en leeftijd

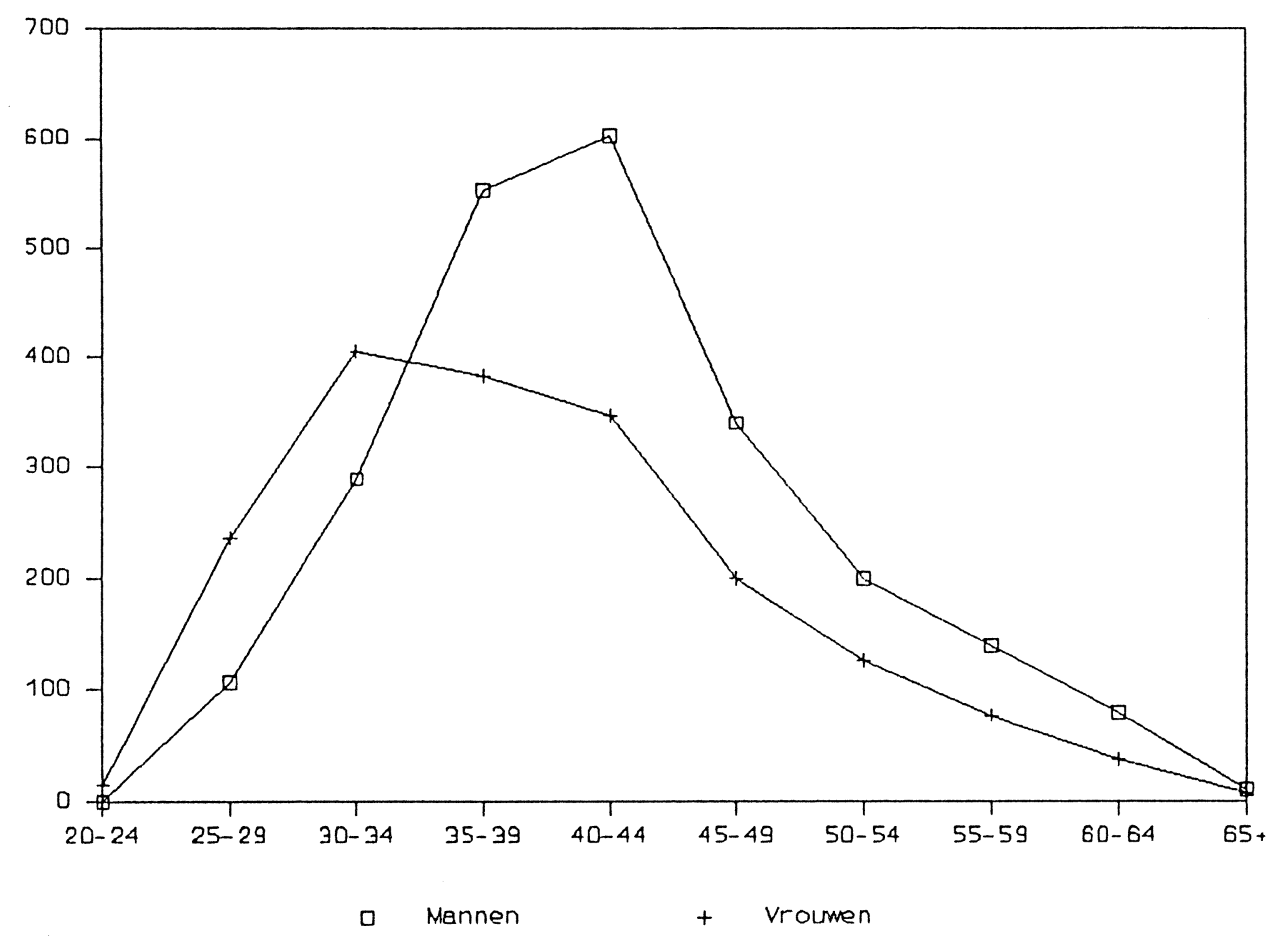

Met behulp van nationale gegevens over de huidige en toekomstige deelnemingspercentages naar geslacht per leeftijdsgroep (CPB, 1983) en de sterftekansen naar geslacht per leeftijdsgroep (CBS, 1987) kan per leeftijdsgroep een uitvalpercentage berekend worden. Het deelnemingspercentage geeft aan welk deel van de potentiële beroepsbevolking daadwerkelijk deelneemt in de beroepsbevolking. Het deelnemingspercentage wordt ondermeer beinvloed door arbeidsongeschiktheid, pensionering en de deelname van gehuwde vrouwen. Met behulp van het berekende nationale uitvalpercentage en de verdeling van werkende klinisch psychologen naar leeftijd en geslacht per sector kan per sector de vervangingsvraag naar klinisch psychologen worden bepaald. Voor nadere informatie over de 
werkwijze die hier is gevolgd, wordt verwezen naar bijlage 11. De uit de berekeningen resulterende vervangingsvraag per sector in de periode 19901995 staat vermeld in tabel 4.

Voor vrouwen in dit beroep geldt echter waarschijnlijk niet het nationale patroon van uittreding uit de arbeidsmarkt. Het valt te verwachten dat, mede gezien de mogelijkheden tot part-time werken, de uittrede van vrouwelijke psychologen op jonge leeftijd vanwege een gezin minder groot zal zijn dan het nationale gemiddelde. Daarom is de vervangingsvraag ook berekend onder de aanname dat het deelnemingspatroon van vrouwelijke psychologen gelijk is aan dat van mannelijke psychologen. De resultaten hiervan staan ook vermeld in tabe 14.

Er moet worden opgemerkt dat, wanneer jonge psychologen onder de NIP-leden ondervertegenwoordigd zijn, deze tabel een enigszins vertekend beeld geeft. In dat geval zal de werkelijke vervangingsvraag iets lager zijn dan hier is berekend.

Tabe1 4. Vervangingsvraag per sector 1990-1995 (in procenten van de werkgelegenheid per 31-121989)

Sector

Sector
Vervangingsvraag

$\%$
Alternatieve

vervangingsvraag*

$\%$

$\begin{array}{lrr}\text { Intramurale gezondheidszorg } & 10,5 & 8,6 \\ \text { Maatschappelijke dienstverlening } & 13,4 & 12,1 \\ \text { Openbaar bestuur } & 9,1 & 8,0 \\ \text { Onderwijs } & 15,1 & 12,8 \\ & & \\ \text { Gemiddelde } & 12,3 & 10,7\end{array}$

\footnotetext{
* Bij gelijke deelnemingspatronen voor mannen en vrouwen

Bron: ROA
}

\subsection{Vraag naar klinisch psychologen tot 1995}

In deze paragraaf wordt kort ingegaan op de wijze waarop de prognoses tot stand zijn gekomen. Voor de resultaten van de prognoses wordt verwezen naar paragraaf 4.8 . 
INTRAMURALE GEZONDHEIDSZORG

De prognose van de werkgelegenheid voor klinisch psychologen in de intramurale gezondheidszorg gebeurt op basis van de indexcijfers uit bijlage 10 die zijn bepaald met de SCP-methode en de berekende regressievergelijking die het verband aangeeft tussen het indexcijfer van de behoefte aan voorzieningen en de werkgelegenheid.

\section{EXTRAMURALE ZORG}

In bijlage 6 wordt de historische werkgelegenheid voor psychologen in de extramurale gezondheidszorg weergegeven. De extramurale gezondheidszorg bestaat uit onder meer de ambulante geestelijke gezondheidszorg (AGGZ) en de schoolartsendiensten. De AGGZ valt weer op te delen naar RIAGG's, CAD's en overige instellingen. Omdat er voor deze sectoren geen cijfers voorhanden zijn over het toekomstig voorzieningengebruik, wordt de totale werkgelegenheid in deze sector op basis van extrapolatie van een lineaire trend doorgetrokken naar de toekomst.

\section{OVERIGE SECTOREN}

Voor andere grote sectoren zijn er slechts groeicijfers per bedrijfssector beschikbaar. Verondersteld wordt dat de werkgelegenheid voor psychologen in gelijke mate groeit als de totale werkgelegenheid in de sector. Op basis van de in een eerdere ROA-studie geprognosticeerde groei van het aantal werkzame personen in 1992 ten opzichte van het aantal werkzame personen in 1985 wordt een gemiddeld jaarlijks groeicijfer bepaald (zie De Grip, Heijke en Dekker, 1989, blz. 7 tabel 1). Deze groei staat per SBI-categorie weergegeven in tabel 5.

Tabel 5. Groei van het aantal werkzame personen, 1985-1992

Omschrijving

jaarlijkse groei*

$\%$

Consultancy

2,7

Personeel sselectie

2,7

Onderwijs op HBO-niveau

Onderwijs op WO-niveau

0,5

0,5

* De groeicijfers voor de sector zijn ontleend aan de bedrijfssector waartoe de sector behoort. Bron: ROA 


\subsection{Arbeidsduurverkorting en deeltijdarbeid}

In het begin van de jaren tachtig is de contractuele arbeidsduur per week flink teruggelopen in de sectoren waar klinisch psychologen werken (zie de indexcijfers in bijlage 12). De laatste jaren is er echter op dit punt een stabilisatie opgetreden. Het lijkt dan ook redelijk te veronderstellen dat in de nabije toekomst de contractuele full-time arbeidsduur per week gelijk zal blijven.

De mate waarin bij een gegeven vraag naar klinisch psychologen in arbeidsjaren een bepaald aantal werkzoekenden aan het werk kan, hangt verder af van het aantal uren dat elke werkende per week werkt in afwijking van de contractuele arbeidsduur. De mate warin part-time gewerkt wordt, kan worden afgeleid uit de verhouding tussen het aantal werkzame personen en het aantal arbeidsjaren (P/A-verhouding). Naarmate deze verhouding hoger ligt, kunnen er bij een gegeven aantal arbeidsjaren meer personen aan het werk. De verdeling naar arbeidsduur in 1985 voor de beroepsgroep sociologen, psychologen e.d. staat in tabel 6 weergegeven.

Tabel 6. Verdeling werkzame personen naar arbeidsduur, 1985

Duur

\begin{tabular}{rr}
\hline 15 uur & 4,1 \\
$15-19$ uur & 3,3 \\
$20-24$ uur & 17,8 \\
$25-29$ uur & 2,9 \\
$30-34$ uur & 13,7 \\
$35-39$ uur & 8,3 \\
$40-44$ uur & 47,7 \\
45 uur & 1,7 \\
onbekend & 0,8 \\
Totaal & 100,0 \\
\hline
\end{tabular}

Bron: ROA/CBS

Voor de periode 1990-1994 wordt door het Centraal Planbureau verwacht dat de

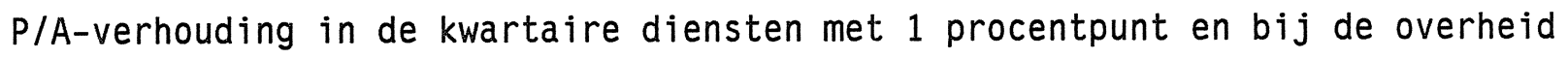
met 0,2 procentpunt zal stijgen (CPB, 1989). Het aantal werkzame personen in deze sectoren zal dus in de komende periode sneller stijgen dan het aantal arbeidsjaren. Deze stijging van de P/A-verhouding wordt veroorzaakt door het 
dalende aantal schoolverlaters in combinatie met het stijgende aandeel van (gehuwde) vrouwen in het arbeidsaanbod.

De gemiddelde arbeidsduur naar geslacht voor een aantal instellingen binnen de intramurale gezondheidszorg is in bijlage 12 weergegeven. Deze arbeidsduur blijkt nogal uiteen te lopen tussen de verschillende instellingen. Ook blijkt de arbeidsduur voor vrouwen en mannen sterk van elkaar te verschillen. Vrouwen hebben over het algemeen een kortere arbeidsduur dan mannen. Aangezien het aantal vrouwen onder de psychologiestudenten nog steeds stijgt, mag worden aangenomen dat dit invloed zal gaan hebben op de gemiddelde arbeidsduur van klinisch psychologen. Deze zal waarschijnlijk lager worden. Een gevolg hiervan is dat er bij een gelijkblijvend aantal arbeidsjaren meer psychologen aan het werk kunnen.

De gemiddelde arbeidsduur volgens tabel 6 is 34,2 uur. Dit betekent bij een normale arbeidsduur van 40 uur dat er per arbeidsplaats 1,17 personen werkzaam kunnen zijn. Verondersteld wordt dat deze factor overeenkomstig de prognose van het Centraal Planbureau nog zal stijgen tot 1,18 in 1995. Voor de contractuele arbeidsduur worden geen veranderingen meer verwacht in de komende periode.

\subsection{Voorlopige prognose}

Op basis van de voorgaande paragrafen kan een voorlopige prognose worden opgesteld, die in tabel 7 wordt weergegeven. Deze voorlopige prognose is tijdens de deskundigen-interviews aan de gesprekspersonen voorgelegd.

Volgens de voorlopige prognose bedraagt de totale uitbreidingsvraag 200 à 300 arbeidsjaren. De totale vervangingsvraag bedraagt ongeveer 300 arbeidsjaren. De totale vraag wordt dan 500 à 600 arbeidsjaren. Omgerekend naar werkzame personen op basis van het geprognosticeerde aantal werkzame personen per arbeidsplaats betekent dit werkgelegenheid voor 600 à 700 nieuwe klinisch psychologen in de komende vijf jaar. 
Tabel 7. Voorlopige prognose van de werkgelegenheidsgroei voor klinisch psychologen in de gezondheidszorg en enkele verwante sectoren, $1990-1995^{*}$ :

\section{Intramurale gezondheidszorg}

Uitbreidingsvraag:

arbeidsvolume

31-12-1989

Ziekenhuizen

Psychiatrische ziekenhuizen

Verpleeghuizen

Zwakzinnigeninrichtingen

Medische kindertehuizen

Medische kleuterdagverblijven

Inr. voor zintuiglijk gehand.

Totaal

Vervangingspercentage $10,5 \%$

\section{Extramurale gezondheidszorg}

School artsendiensten

RIAGG

CAD

Overig

Eerstel ijnspraktijken

Totaal

Vervangingspercentage $13,4 \%$

* 1-1-1990 - 1-1-1995

Bron: ROA
390

5 à $8 \%$

466

1 à $6 \%$

59

$10 \%$

145

2 à $8 \%$

12

$0 \%$

30

13 à $16 \%$

13

9 à $11 \%$

1115

23

$0 \%$

800

16 à $20 \%$

53

6 à $8 \%$

12

$0 \%$

245

9 à $11 \%$ 


\section{RESULTATEN VAN DE DESKUNDIGEN-INTERVIEWS}

\subsection{Inleiding}

In dit hoofdstuk wordt verslag gedaan van de elf interviews die zijn gehouden met 'sleutelpersonen' uit het veld11. Het doel van deze interviews was het bijstellen van de voorlopige prognose op basis van nadere gegevens en actuele ontwikkelingen. De sleutelpersonen zijn geselecteerd op basis van hun kennis van de arbeidsmarkt voor klinisch psychologen binnen een bepaalde sector van de gezondheidszorg. Deze interviews leverden zeer waardevolle informatie op voor bijstelling van de voorlopige prognose, voor potenties en bedreigingen en voor ideeën over de op te stellen varianten.

Deze elf personen zijn in overleg met de begeleidingscommissie geselecteerd. Bij de selectie werd getracht een evenwichtige verdeling te vinden over de diverse sectoren van de gezondheidszorg waar klinisch psychologen werkzaam zijn. De sleutelpersonen zijn vervolgens door het NIP verzocht om medewerking te verlenen aan de interviews. Vóor het gesprek is een lijst met gespreksthema's en de voorlopige prognose, voorzien van een korte inleiding, naar de te interviewen personen verzonden. Tijdens de gesprekken is de respondent eerst gevraagd naar enkele verwachtingen over de werkgelegenheidsontwikkeling van klinisch psychologen in de desbetreffende sector. Daarna is nader ingegaan op de gemaakte prognose.

Van elk gesprek is een verslag gemaakt dat aan de respondenten ter goedkeuring is voorgelegd. Zonodig werd het verslag aangepast. In de hierna volgende paragrafen worden de resultaten van de interviews besproken per sector.

Uit de gevolgde werkwijze vloeit voort dat de in dit hoofdstuk gepresenteerde uitspraken de opinies weergeven van de respondenten uit het veld en niet die van de onderzoekers of van de leden van de begeleidingscommissie.

11. De hiervoor gebruikte lijst met gespreksthema's is opgenomen in bijlage 13. 


\subsection{Intramurale gezondheidszorg}

\subsubsection{Algemene zziekenhuizen}

De psycholoog in het algemene ziekenhuis heeft een functie naar de patiëntenzorg toe door middel van psychologisch onderzoek en behandeling (directe patiëntenzorg) en door middel van activiteiten die niet aan individuele patiënten gebonden zijn (indirecte patiëntenzorg) (NRV, 1988). Volgens onze respondenten is er nog veel ruimte voor klinisch psychologen. Er ontstaan op dit moment veel nieuwe aandachtsvelden waarbij de inzet van psychologen gewenst is, zoals hulpverlening met betrekking tot Aids, hulpverlening aan ouderen en terminale zorg. Volgens de respondenten valt er echter, voor het zover is, nog veel weerstand te overwinnen bij de medische stand. De medische opleiding levert namelijk nog onvoldoende kennis van de psychologie om een duidelijke taak voor de psycholoog te zien.

Voor psychologen is vooral groei mogelijk op plaatsen waar vroeger geen ruimte voor een psycholoog was, bijv. in kleine ziekenhuizen, op interne afdelingen (vooral cardiologie), maar ook poliklinisch.

Vroeger was er een richtlijn voor het aantal psychologen per psychiatrische afdeling van het algemene ziekenhuis (PAAZ) of per 300 bedden. Bij de invoering van budgetfinanciering werd dit bedrag opgenomen in een totaal budget. $\mathrm{Nu}$ de totale budgetten afnemen en de materiaal- en medicijnkosten toenemen, is er een flinke weerstand op het aannemen van personen voor functies die ter discussie staan (zoals psychologen). Voor de nabije toekomst bestaat bovendien de kans dat de staatssecretaris van Volksgezondheid op de algemene ziekenhuizen zal bezuinigen (gezien zijn plannen met de andere sectoren). In dat geval is een groei van het aantal functies voor klinisch psychologen in algemene ziekenhuizen van 5 à $8 \%$ in 5 jaar te optimistisch.

\subsubsection{Intramurale en semi-murale_psychiatrische zorg}

\section{Algemene psychiatrische ziekenhuizen}

In de psychiatrische ziekenhuizen bestaat er steeds minder behoefte aan klinisch psychologen. De 'praatcultuur', zo wordt gesteld, is ten einde en er wordt weer meer aandacht besteed aan directe verzorging. Het motto is 
daarbij: "Handen aan het bed". Er wordt daarom volgens de respondenten bij vervanging of uitbreiding van het huidige personeel de voorkeur gegeven aan verplegend personeel boven staf. Daardoor zullen er, vooral op de langere termijn, minder psychologen worden ingezet. Bovendien komen er op de langere termijn ook meer opleidingsplaatsen voor psychiaters, waardoor de mogelijkheden voor psychologen als psychotherapeut verder zullen afnemen.

De door de overheid gewenste verschuiving van intramurale zorg naar de extra- en semimurale zorg is volgens onze respondenten in de psychiatrie nog niet waar te nemen (zie ook Financieel Overzicht Zorg 199012). Er komt weliswaar meer aandacht voor extramurale zorg, maar de bezettingsgraad in de psychiatrische ziekenhuizen verandert daardoor nauwelijks. Er komen bijvoorbeeld beschermde woonvormen, waarin geen voormalige patiënten uit de intramurale psychiatrische zorg terecht komen maar een nieuwe populatie (bijv. zwervers), zodat de bezetting in de intramurale zorg niet afneemt.

Door deze ontwikkelingen zal het aantal psychologen in psychiatrische ziekenhuizen naar verwachting niet stijgen, maar eerder afnemen. In het meest gunstige geval zal het aantal stabiel blijven. Er spelen echter meer ontwikkelingen een rol. De psychologen moeten in de algemene psychiatrische ziekenhuizen concurreren met matschappelijk werkers (met een therapeutische opleiding op HBO-niveau) en orthopedagogen. Door deze concurrentie staat de positie van de psycholoog onder druk. Vanwege kostenoverwegingen worden psychologen, die nieuw worden aangenomen, intern opgeleid. Het voordeel hiervan is dat ze lager kunnen worden ingeschaald dan de gebruikelijke schaal, terwijl de kosten van het zelf opleiden lager zijn dan het extra salaris van een hogere schaal. Ook werd door respondenten gesproken van een revival van de psychiater. De mate waarin bij een vacature voor een psychiater/psychotherapeut een psychiater zal worden aangenomen hangt echter af van de beschikbaarheid van psychiaters. Als het huidige gebrek aan psychiaters niet wordt opgelost, zal deze revival geen merkbare invloed op de werkgelegenheid van klinisch psychologen hebben.

Conclusie: de rol van de psycholoog in de psychiatrische ziekenhuizen zal de komende periode steeds verder onder druk komen te staan. Dit zal zich waarschijnlijk uiten in een afname van het aantal psychologen en een lagere beloningsschaal.

12. Tweede Kamer, 1989. 
TBS-instellingen

De instellingen voor het ter beschikking stellen van delinquenten (TBS) kunnen worden onderverdeeld in twee soorten instellingen, namelijk de rijksinrichtingen en de particuliere inrichtingen. Bij de rijksinrichtingen werken ongeveer 22 psychologen. In de particuliere sector werken ongeveer evenveel psychologen. De taken van deze psychologen bestaan uit diagnostisch en therapeutisch werk. De psychologen bij de TBS-instellingen hebben betrekkelijk weinig therapie in hun werkzaamheden. Het werk bestaat voor $40 \%$ uit diagnostiek, de rest is therapie en leidinggeven (steeds meer behandelingscoördinatie).

Er zal een nieuwe TBS-instelling bijkomen en de capaciteit van de bestaande inrichtingen zal verder worden uitgebreid. Op basis hiervan wordt door de respondenten een werkgelegenheidsgroei verwacht van 10 à $15 \%$ in 5 jaar (op een huidig totaal van 40 mensen). Hierbovenop komt nog een extra groei vanwege de verwachte effectuering van de bredere inzetmogelijkheden van psychologen in plaats van psychiaters. Vooral voor psychotherapie worden gekwalificeerde psychologen gebruikt in plaats van psychiaters.

\section{Overige psychiatrische instellingen}

In de verslavingsklinieken is het personeelsbestand in de periode 1983-1988 gestegen met 3,3\% per jaar (Financieel Overzicht Zorg 199013). De verslavingsproblematiek zal naar verwachting de komende jaren nog sterk in omvang toenemen. Voor de verslavingsklinieken wordt daarom een voortzetting van deze groei verwacht. Door de functie van de psycholoog bij de verslavingsproblematiek zal deze groei bovendien erg belangrijk zijn voor psychologen.

In de kinder- en jeugdpsychiatrische inrichtingen was de groei van het gehele personeelsbestand in de periode 1983-1988 6,1\% per jaar (Tweede Kamer, 1990). Ook voor de toekomst wordt rekening gehouden met een flinke groei van de werkgelegenheid.

Semimurale psychiatrische zorg

Door respondenten werd opgemerkt dat een psycholoog op nuttige wijze tijd

13. Tweede Kamer, 1989. 
zou kunnen invullen in het kader van de verplichte 4-uursbehandeling in de instellingen voor beschermd wonen. Dit stelt wel bepaalde eisen aan de psycholoog qua opleiding, maar een psycholoog wordt hiervoor beter geschikt bevonden dan bijvoorbeeld een matschappelijk werker. Door de stimulering door de overheid van de verschuiving van intramurale zorg naar semimurale zorg kan hier nog een groeiend werkterrein voor psychologen liggen. Het is echter zeer onduidelijk in welke mate deze ontwikkeling zal worden gerealiseerd en of hiervoor daadwerkelijk psychologen zullen worden ingeschakeld.

\subsubsection{Verpleeghuizzen}

De psycholoog in het verpleeghuis werd vroeger aangetrokken voor de diagnostiek en de daarop aansluitende behandeling. In de verpleeghuizen is daarna op het eind van de jaren '70 en het begin van de jaren '80 meer aandacht gekomen voor het leefklimaat, dat wil zeggen voor het psychosociaal functioneren van de patiënten. In die periode zijn er dan ook veel psychologen aangenomen. De categorie Medisch en Sociaal Wetenschappelijke staf (waartoe de psychologen behoren) is daarna in de periode 1983-1988 nog gegroeid met $5,5 \%$ per jaar (Financieel Overzicht Zorg 199014).

Enkele jaren geleden bestonden er nog hoge verwachtingen ten aanzien van het functioneren van de psycholoog in verpleeghuizen. Volgens de respondenten zijn tegenwoordig de verwachtingen verdeeld. Andere beroepsgroepen zoals de verpleeghuisartsen en ergotherapeuten slagen er thans beter in dan de verpleeghuispsychologen om zich duidelijk te profileren. De psychologen 'timmeren niet voldoende aan de weg', zo wordt gesteld.

Al enige tijd geleden is de capaciteit van de 330 verpleeghuizen bevroren. Daarom zal het aantal psychologen in verpleeghuizen ten hoogste stabiel blijven, tenzij de psychologen nieuwe terreinen weten te ontwikkelen. In het laatste geval is er nog wel groei mogelijk van het aantal psychologen. Een nieuw terrein is bijvoorbeeld het werken op consultbasis voor een verzorgingstehuis. Er is namelijk sprake van een duidelijke verschuiving van patiënten van het verpleeghuis naar het verzorgingstehuis. Hierdoor is de overlap tussen beide categorieën instellingen groter geworden (15\%) en is er vaker consultatie van een psycholoog nodig in verband met de mogelijke

14. Tweede Kamer, 1989. 
opname in het verpleeghuis dan wel het handhaven van de betreffende oudere in het verzorgingstehuis.

Voor het bovengenoemde terrein van diagnostiek bij patiënten in het verzorgingstehuis of thuis is in sommige verpleeghuizen een aparte observatieafdeling ingericht. Ook voor consultatie naar de (1600) verzorgingstehuizen toe ligt er een behoorlijk werkterrein met betrekking tot depressies, geheugenproblemen, eenzaamheid en eerste stadia van dementie. Hiervoor worden de financiële mogelijkheden ook steeds ruimer. De afgelopen jaren is dit gebruik tot reguliere aanpak geworden en de subsidie voor zorgprojecten waarin onder meer ook de consultatie door de verpleeghuispsycholoog een rol speelt is nu ook aan te vragen door het verzorgingstehuis.

Advisering door de psycholoog bij groepsverzorging begint van de grond te komen. Ook ligt er een deeltaak voor de verpleeghuispsycholoog buiten het verpleeghuis met betrekking tot preventie bij gezonde ouderen, bijvoorbeeld het geven van geheugencursussen. Verder is de somatiek voor de psycholoog veelal nog onontgonnen terrein. Dit is de begeleiding van de patiënt naar de eigen leefsituatie (met de eventuele mogelijkheid tot eerder ontslag uit het verpleeghuis), acceptatie van de handicap e.d.

De belangrijkste concurrentie voor de verpleeghuispsychologen komt van de RIAGG's. Deze concurrentie geldt ook voor de rol van de verpleeghuispsycholoog in het verzorgingstehuis. Vooral als de huidige wachtijjsten bij de RIAGG's verdwijnen zal deze concurrentie belangrijker worden.

Conclusie: Het gevolg van enerzijds de grotere aandacht voor verpleging en verzorging en anderzijds de toenemende vergrijzing is dat voor de psychologen in verpleeghuizen waarschijnlijk een stabilisatie van de werkgelegenheid zal optreden.

\subsubsection{Zwakzzinnigeninrichtingen}

In de afgelopen periode is er in de semimurale zwakzinnigenzorg een sterke groei geweest. Deze deed zich vooral voor in de gezinsvervangende tehuizen (GVT). Volgens het Financieel Overzicht Zorg 1990 (Tweede Kamer, 1989) was de groei van de beddencapaciteit bij de dagverblijuen in de periode 1983$19885,1 \%$ per jaar en bij de gezinsvervangende tehuizen 5,5\% per jaar. 
Door de plannen van de staatssecretaris voor Volksgezondheid wordt voor de zwakzinnigenzorg in de toekomst een einde van de wachtijjstproblematiek verwacht. Hiervoor zouden er enkele duizenden bedden bij moeten komen en dus ook meer personeel. Voor de werkgelegenheid geldt immers dat in principe de staf in verhouding met de beddencapaciteit zal mee stijgen. Hier liggen dus kansen voor psychologen. In veel gevallen zal echter de voorkeur worden gegeven aan een orthopedagoog boven een klinisch psycholoog. De psychiaters vormen op dit terrein geen concurrenten, omdat psychiaters die gespecialiseerd zijn in de zwakzinnigenzorg schaars zijn. Bovendien is de inzet van een psychiater bij de hulpverlening vaak niet nodig. Deze verschuiving van taken naar de orthopedagoog hangt samen met het streven naar verzorging ("alle handen aan het bed"). Deze besparing aan duurdere psychologen kan namelijk besteed worden aan extra verzorging. Een eventuele professionalisering zal vooral worden bereikt door scholing van het verplegend personeel en niet door het aannemen van meer staf.

Een groei van $8 \%$ in de komende 5 jaar voor het aantal klinisch psychologen in deze sector is vanwege bovengenoemde redenen naar de mening van de respondenten nogal optimistisch. Het groeipercentage voor klinisch psychologen zal daarom volgens de respondenten waarschijnlijk eerder $2 \%$ zijn dan $8 \%$ in de komende periode.

Conclusie: er gelden matige perspectieven voor klinisch psychologen in deze sector. De toegevoegde waarde van een klinisch psycholoog boven bijvoorbeeld een orthopedagoog is niet duidelijk.

\subsubsection{Medische kindertehuizen en kleuterdagverblijjven en inrichtingen} voor zintuigiglijk﹎. gehandicapten

De medische kindertehuizen en de medische kleuterdagverblijven zijn sinds enkele jaren uit de gezondheidszorg verdwenen en ondergebracht onder de jeugdhulpverlening. In deze sectoren verdwijnen dure beroepsgroepen zoals de psychologen geleidelijk. Het aantal klinisch psychologen in deze sector zal daarom in de nabije toekomst waarschijnlijk blijven dalen. 


\subsection{Extramurale gezondheidszorg}

\subsubsection{Schoolartsendiensten}

In deze diensten is volgens onze respondenten zeker plaats voor klinisch psychologen, vooral in de grote centra. De hulpverlening kan echter ook via een RIAGG gebeuren. Daarom is het waarschijnlijk dat het aantal klinisch psychologen, werkzaam bij de schoolartsendiensten, stabiel blijft.

\subsubsection{RIAGG}

Binnen de RIAGG's (Regionale Instellingen voor Ambulante Geestelijke Gezondheidszorg) zal in toenemende mate plaats zijn voor psychologen mits deze inzetbaar zijn in de sociale psychiatrie en in de psychotherapie. Deze beide terreinen dienen daarom in de opleiding van de psycholoog te zitten. Een op dergelijke wijze opgeleide psycholoog heeft sterk de voorkeur ten opzichte van een maatschappelijk werkende, ook al is de laatste goedkoper. Verder zal een dergelijke psycholoog ook effectief kunnen concurreren met de psychiater. In de psychotherapie zal het aantal psychologen evenwel eerder afnemen dan toenemen.

De RIAGG's zullen hun aandacht waarschijnlijk sterk gaan concentreren op die terreinen waarvoor de instituutsvorm noodzakelijk is. Dit is met name het geval bij de combinatie van sociale psychiatrie en psychotherapie. Hierbij is de psycholoog zeer belangrijk, die tevens goed bereikbaar moet zijn. Het laatste betekent dat er waarschijnlijk minder part-timers zullen worden aangenomen (en dit verkleint de kansen voor herintreders).

De 'lichte' hulpverlening (voornamelijk psychotherapie), kan gedeeltelijk worden overgenomen door zelfstandig gevestigde psychologen. Daarvoor is dan wel nodig dat consultatie van zelfstandig gevestigde psychologen door de AWBZ-financiering wordt betaald. Mocht deze verschuiving werkelijk optreden dan geldt voor de RIAGG's een lagere verwachte groei.

De eindconclusie is dat voor de psychologen bij de RIAGG's er maximaal $10 \%$ werkgelegenheidsgroei in de komende 5 jaar wordt verwacht. Deze zal vooral vorm krijgen in een verschuiving van disciplines in de richting van de psychologen ten koste van de maatschappelijk werkenden. 


\subsubsection{CAD}

Voor de Consultatiebureau voor Alcohol en Drugs (CAD) geldt dat er ruimte is voor psychologen in plaats van matschappelijk werkenden, omdat een psycholoog meer mogelijkheden op dit terrein heeft. Ook ontwikkelingen in de verslavingszorg, zoals de toegenomen aandacht voor gokverslaving, hebben een positief effect op de functie van de psycholoog bij de CAD's. Een nadeel is echter dat sinds kort de financiering van de CAD's plaatsvindt door de gemeenten. Bij de meeste gemeenten bestaat volgens de respondenten hoofdzakelijk belangstelling voor de matschappelijke aspecten van verslaving zoals openbare orde en non-proliferatie. De nadruk kan hierdoor meer op opvang en minder op behandeling komen te liggen. Bovendien is een psycholoog duur vergeleken met een matschappelijk werkende. Als gevolg hiervan is de ontwikkeling van de werkgelegenheid van klinisch psychologen bij de CAD's nogal onzeker.

\subsubsection{Eerstel $\underline{j}$ jnsprakt}

\section{Eerstelijnspraktijken}

Volgens respondenten doen zich op de markt voor eerstelijnspraktijken verzadigingstendenties voor. De groei van het aantal eerstelijnspsychologen in het verleden is gedeeltelijk het gevolg geweest van een slechte arbeidsmarktsituatie. Men trachtte een functie te vervullen in de eerste lijn, al was het maar voor enkele uren per week, om langs die weg de nodige kwalificaties te verkrijgen. Door de komst van de Regionale Instituten voor Nascholing en Opleiding (RINO) zal dit wellicht moeilijker worden, omdat de vereiste kwalificaties dan bij deze instellingen moeten worden verkregen.

Bij de uitvoering van de plannen van de Commissie Dekker voor de gezondheidszorg zouden er goede kansen worden geboden voor psychologen in de eerste lijn, als het voorstel zou worden overgenomen om de eerstelijnspraktijken op te nemen in het verstrekkingenpakket van de AWBZ. Volgens de recente plannen van de staatssecretaris voor Volksgezondheid zal dit echter waarschijnlijk niet gebeuren.

Op het terrein van de eerstelijnszorg kan de psycholoog goed samenwerken met maatschappelijk werkers en huisartsen, omdat hier sprake is van een duide- 
lijke taakafbakening. De psycholoog moet hier echter wel concurreren met bijvoorbeeld de orthopedagoog en met de hulpverlening door het RIAGG, dat immers 'gratis' hulp biedt.

De concurrentiepositie van de RIAGG's ten opzichte van de eerstelijnspsychologen zou kunnen verzwakken door het uitvoeren van de ideeën van het plan Dekker, met betrekking tot de doorvoering van een grotere regionale autonomie bij de toewijzing van middelen aan de onderscheiden functies in de geestelijke gezondheidszorg, en het opvolgen van de latere adviezen over een functiegerichte benadering in deze sector. Het RIAGG dat zoveel verschillende functies in zich verenigt zou dan overbodig kunnen worden. Zolang de beoogde functiegerichte benadering van de geestelijke gezondheidszorg geen gestalte heeft gekregen, zullen de RIAGG's hun huidige taken blijven vervullen en weinig ruimte laten voor andere initiatieven.

Conclusie: Omdat naar de mening van de respondenten het onwaarschijnijjk is dat het verzekeringspakket wordt uitgebreid met voorzieningen voor de geestelijke gezondheidszorg in eerstelijnspraktijken, lijkt een lage, stabiele groei van het aantal eerstelijnspraktijken de meest waarschijnlijke ontwikkeling.

\section{Samenwerkingsverbanden met huisartsen}

Volgens verschillende respondenten is de 'toegevoegde waarde' van de klinisch psychologen in de gezondheidszorg vooral gelegen in hun bijdrage aan het diagnostiseren en behandelen van 'vage klachten'. Vooral in de algemene ziekenhuizen en in de eerstelijnszorg zou die toegevoegde waarde de efficiëntie van de zorg kunnen bevorderen. Daarvoor is in de algemene zorg een goede samenwerking tussen huisarts en klinisch psycholoog nodig. In dit verband is de opkomst van zogenaamde waarneemgroepen van belang. Dit zijn samenwerkingsverbanden tussen 4 à 10 huisartsen. Deze zijn in eerste instantie bedoeld voor het bevorderen van de continuiteit van de praktijk door het regelen van diensten en vakanties. Ze bieden echter ook mogelijkheden voor overleg en scholing, en eventueel ook voor taakverdeling. De waarneemgroep kan contracten afsluiten met de zorgverzekeraars. Binnen een dergelijk contract kan samengewerkt worden met een klinisch psycholoog. Hierdoor zou er (theoretisch) ruimte ontstaan, zo is opgemerkt, voor 750 à 1000 psychologen, met als taak:

- assisteren van de huisarts bij het stellen van de diagnose; 
- consultaties verrichten (als de huisarts vastloopt);

- deskundigheidsbevordering voor artsen;

- behandeling (kortdurend, max. 10 sessies).

Als deze ontwikkeling inderdaad optreedt kan er een verschuiving plaatsvinden van het RIAGG naar de eerstelijn. In dat geval zal de werkgelegenheid bij het RIAGG dalen. Van de huidige RIAGG-activiteiten kan dan, zoals werd gesteld, ongeveer de helft door de eerstelijn of door de waarneemgroepen worden overgenomen.

Bij de verwijzing vanuit de eerstelijn geldt een sterke concurrentie tussen de klinisch psycholoog, de orthopedagoog, de psychiater en de maatschappelijk werkende. Hoewel allen in principe een eigen terrein hebben, zit tussen de terreinen van de diverse disciplines een groot grijs gebied. Daarbinnen is sprake van individuele voorkeuren en tamelijk willekeurige situaties. Zo kan bijvoorbeeld een particulier verzekerde patiënt naar een psychiater worden verwezen, omdat deze verwijzing voor de patiënt vergoed wordt en een verwijzing naar een psycholoog niet, hoewel verwijzing naar een psycholoog gezien de klacht meer voor de hand had gelegen.

Het is dus van groot belang of de psycholoog in het pakket van de zorgverzekeraars wordt opgenomen. Het argument voor de zorgverzekeraars in deze zou dan zijn dat de psycholoog in de eerste lijn in sommige gevallen een verwijzing naar een specialist (en daarmee een flinke sleep van kosten) kan uitsparen. In het geval van opname van psychologisch hulp in het verstrekkingenpakket door de zorgverzekeraars zal de samenwerking van de psychologen met de huisartsen, bijvoorbeeld binnen een huisartsengroep, sterk worden bevorderd.

Conclusie: Als de bekostiging van de psychologische hulp in de AWBZ wordt opgenomen en de positie van en de eisen voor klinisch psychologen goed worden geregeld, dan kan er nog een flinke groei van de werkgelegenheid van klinisch psychologen in de eerste lijn optreden. Het is echter onwaarschijnlijk dat deze flinke groei zich in de nabije toekomst zal realiseren.

\subsection{Justitie}

De psychologen die werkzaam zijn bij Justitie kunnen werkzaam zijn bij de TBS-instellingen, bij het gevangeniswezen of bij de kinderbescherming. De werkgelegenheid van psychologen bij de TBS-instellingen werd reeds bij de 
psychiatrische instellingen behandeld.

In het gevangeniswezen werken ruim 30 psychologen in vaste dienst. $Z i j$ doen voornamelijk coördinerend werk. Daarnaast zijn er psychologen werkzaam op uurbasis, die rapporteren als getuigedeskundige aan de rechtbank. Dit soort activiteiten neemt sterk toe. Vanwege de wettelijke vereisten wordt bij het vooronderzoek vaak een psycholoog ingeschakeld15. Bovendien is het vanwege de wettelijke vereisten zelfs verplicht een psycholoog en een psychiater te betrekken bij de verlenging van de TBS na vier jaar. Bij deze werkzaamheden vindt nauwelijks therapeutische behandeling plaats.

Voor het gevangeniswezen wordt een groei van 15 à $20 \%$ in de komende 5 jaar verwacht. Voor de advisering door psychologen aan de rechtbank wordt een spectaculaire groei verwacht. Dit hangt echter ook af van het doorgaan van de uitbreiding van het Openbaar Ministerie, omdat dit op dit moment een knelpunt vormt. De genoemde groei betekent een werkgelegenheidsgroei voor zowel psychologen die bij Justitie in dienst zijn als externe psychologen. Het advieswerk als getuige-deskundige stelt overigens wel specifieke eisen aan de psychologen.

Bij de kinderbescherming werken ongeveer 12 psychologen. Zij plegen daar psychodiagnostiek, verrichten een enkele behandeling en verzorgen de begeleiding. Bij de jeugdinrichtingen wordt ook groei van de werkgelegenheid verwacht. Hier zal in de komende periode minder aandacht voor opvang zijn en meer aandacht voor behandeling, zodat het aantal plaatsen voor psychologen eventueel kan verdubbelen.

Justitie heeft te maken met een groeiend aantal psychisch gestoorden. Bij de TBS-inrichtingen komen steeds meer psychotische gevallen en bij het gevangeniswezen komen steeds meer mensen met psychische stoornissen en ontwikkelingsstoornissen (de voormalige TBS-populatie). Ook daarom zijn er bij Justitie meer klinisch psychologen nodig.

Voor Justitie wordt het probleem gesignaleerd of men bij een groeiende behoefte in staat zal zijn om aan voldoende psychologen te komen, omdat Justitie als werkgever niet erg in trek is. Ook nu al moeten er bij Justitie

15. De wettelijke vereisten spreken hier overigens van een sociale wetenschapper. 
psychologen intern opgeleid worden, die vervolgens na het behalen van de benodigde kwalificaties blijken te vertrekken naar de geestelijke gezondheidszorg. Werken voor Justitie is niet aantrekkelijk, omdat het advieswerk aan de rechter nogal risicovol is vanwege de eventuele negatieve publiciteit bij (vermeende) fouten. Buiten de al genoemde problemen is er bij Justitie ook nog een verslechtering op komst van de arbeidsvoorwaarden voor psychologen, zodat de aantrekkelijkheid als werkgever nog verder zal afnemen.

\subsection{Kruisverenigingen}

Het doel van het kruiswerk is het bevorderen van de extramurale gezondheidszorg. De financiering gebeurt door ledengeld, AWBZ-geld en door verzekeraars. Er werken voornamelijk verplegenden en medici, maar er zijn ook andere disciplines vertegenwoordigd, zoals bijvoorbeeld psychogerontologen en pedagogen. In principe worden mensen met psychische problemen doorverwezen naar een RIAGG, maar deze instelling heeft een hoge drempel en lange wachtijijsten. Voor het kruiswerk zou een betere situatie ontstaan als er een psycholoog in deze eerstelijnsinstelling zou worden opgenomen. Men geeft hieraan de voorkeur boven een verwijzing naar een vrijgevestigde psycholoog. Bij een enkele kruisvereniging is reeds een psycholoog werkzaam, maar bij de meeste nog niet.

Voor de werkgelegenheid van psychologen in het kruiswerk lijkt een groei van 9 à $10 \%$ in de komende vijf jaar wel redelijk. De psycholoog kan binnen het kruiswerk echter ook worden ingezet voor preventie. De wijze van financiering is hiervoor echter cruciaal. De zorgverzekeraars zijn nogal sceptisch over de mogelijkheid dat substitutie van kosten zal optreden. In de praktijk van het kruiswerk wordt het nut echter wel onderkend. Daarom zullen de kruisverenigingen misschien toch wel psychologen aannemen, ook zonder dat er financiering plaatsvindt door de zorgverzekeraars. Volgens de mening van respondenten zou er bij de ongeveer 60 kruisverenigingen dan plaats zijn voor $24 \mathrm{klinisch}$ psychologen. De opvulling van deze ruimte kan echter ook door andere disciplines gebeuren. Er geldt echter wel dat voor de ondersteuning van de wijkverplegenden in elk geval ervaring met brede, algemene hulpverlening is vereist.

Conclusie: er is voldoende ruimte voor de klinisch psycholoog in de eerstelijn mits deze een consultatierol kan vervullen bij instellingen als het kruiswerk en het maatschappeijjk werk en mits deze hulp in het 
vergoedingenstelsel wordt opgenomen. Gezien het geringe aantal van de klinisch psychologen en de grote onzekerheid van een aantal factoren wordt voor deze sector evenwel geen kwantitatieve invulling van de prognose gemaakt.

\subsection{Buitenland}

Door bijna alle respondenten worden de werkgelegenheidseffecten van het buitenland afgedaan als een irrelevante factor vanwege de taalbarrière. Verder wijst men op de problemen met de internationale erkenning van diploma's. Bovendien geldt voor de intramurale zorg dat alle Europese landen in een vergelijkbare situatie zitten. $\mathrm{Er}$ is meer verpleging gewenst bij gelijkblijvende of dalende budgetten, waardoor de arbeidsplaatsen voor onder meer klinisch psychologen onder druk staan.

Wel is het zo dat er een aantal Belgische klinisch psychologen in Nederland werkzaam is, maar deze hebben echter vaak ook hun opleiding in Nederland gehad.

Een respondent noemde nog een potentiële markt voor Nederlandse psychologen in Frankrijk, Spanje of Duitsland, omdat in deze landen een enorme behoefte is aan klinisch psychologen. Ook hier is het cruciaal dat de psychologen de taal beheersen en zich geografisch mobiel weten op te stellen.

\subsection{Nieuwe werkterreinen}

Door een enkele respondent werd benadrukt dat de groei van de werkgelegenheid voor klinisch psychologen voor het overgrote deel ligt buiten het terrein van de traditionele gezondheidszorg. Vooral op het terrein van arbeid en gezondheidszorg is er veel groei van de werkgelegenheid voor klinisch psychologen mogelijk, omdat deze beter gekwalificeerd zijn voor een individuele benadering dan arbeids- en organisatiepsychologen.

Ook is er veel groei mogelijk in nieuwe gebieden zoals bijvoorbeeld het Instituut voor Psychotrauma, voor opvang bij ongelukken, overvallen e.d. en het Landelijk Steunpunt Rouwbegeleiding. Voor dit soort hulp, die ook in de somatische zorg plaatsvindt, worden nieuwe mensen ingeschakeld met een andere houding en vakbeleving. Deze nieuwe mensen worden vaak ingeschaald als maatschappelijk werkenden. 
Ook binnen de traditionele gezondheidszorg zijn er enkele nieuwe terreinen. Genoemd werden de gezondheidspsychologie in bijvoorbeeld kankercentra en ziekenhuizen. De rol van de psycholoog betreft hier het leren omgaan met ziekten, handicaps en pijn. Hier is veel ruimte voor psychologen en er is ook het inzicht aanwezig dat een psycholoog nodig is voor deze taken. Ook werd de revalidatie genoemd als een voor psychologen zeer belangrijk en groeiend werkterrein.

Verder kan er voor psychologen een plaats zijn in het management van de zorgsector, mits in de opleiding daaraan aandacht is geschonken. Gezien de toekomstige vervangingsvraag en door te voeren herstructurering van de sector is daaraan zeker behoefte. Voor deze functie is echter geen klinische specialisatie noodzakelijk, zodat hiermee geen rekening wordt gehouden bij de prognoses.

\subsection{Conclusies van de deskundigen-interviews}

In de extramurale zorg wordt door de respondenten bijna unaniem de toekomstige groei van de werkgelegenheid voor klinisch psychologen bij de RIAGG's lager ingeschat dan de groei in de afgelopen periode. De verwachte groei is hierbij sterk afhankelijk van de mate van verschuiving van de hulpverlening van de RIAGG's naar de eerstelijnspraktijken.

Ook de ontwikkeling van het aantal arbeidsplaatsen voor psychologen bij de CAD's is onzeker, omdat de CAD's sinds kort door de gemeenten worden gefinancierd. Naar analogie met de medische kindertehuizen kan ook hier de relatief dure beroepsgroep van psychologen terrein verliezen. Dit mede omdat volgens de respondenten bij de gemeenten vaak meer belang wordt gehecht aan opvang (door maatschappelijk werkenden) dan aan hulpverlening (door psychologen).

De groei bij de eerstelijnspraktijken wordt nogal wisselend ingeschat. Sommigen verwachten nog een flinke groei (zeker wanneer de samenwerking met de huisartsen beter verloopt), anderen spreken van een verzadigde markt en verwachten een stabilisatie.

Als belangrijke (nieuwe) groeiterreinen worden genoemd:

- de gezondheidspsychologie;

- de forensische psychologie; 
- revalidatiecentra;

- management/leidinggevende functies.

Over het algemeen wordt aan de rol van het buitenland geen grote invloed toebedeeld.

Een zeer belangrijke factor voor de werkgelegenheid van psychologen is de wijze van financiering van de zorg. Als de psychologische hulp via de AWBZ bekostigd gaat worden, zal dit een enorme (positieve) invloed op de werkgelegenheid van psychologen hebben. De kans hierop wordt door de respondenten echter niet groot geacht.

\subsection{Interpretatie van de resultaten van de interviews voor de prognose}

Bij de interpretatie van de gegevens is het goed om in gedachten te houden dat de meeste geïnterviewde personen redelijk optimistisch waren over de mogelijkheden en kansen voor klinisch psychologen. Vaak ontstond echter een geheel ander beeld als de financiering van deze extra werkgelegenheid voor psychologen werd besproken. Dan bleek dat de aanwezige ruimte voor klinisch psychologen waarschijnijjk niet opgevuld zal worden, omdat bij de gegeven situatie met beperkte financiële middelen de voorkeur wordt gegeven aan andere mogelijkheden.

Verder zal er rekening worden gehouden met het optreden van substitutie binnen de verschillende vormen van gezondheidszorg. Zo kan een eventuele groei van de eerstelijnspraktijken gerealiseerd worden ten koste van de werkgelegenheid bij de RIAGG's. Het zou een vertekening van de werkelijkheid geven als daarmee geen rekening wordt gehouden. Een andere mogelijkheid tot substitutie kan plaatsvinden van intramurale naar semimurale zorg. Deze laatste mogelijkheid wordt tegenwoordig door de overheid sterk gestimuleerd.

Naar aanleiding van de reacties en de gegevens die uit de interviews naar voren komen, zal de voorlopige prognose op enkele punten worden bijgesteld. Op de eerste plaats is duidelijk geworden dat de groei bij de RIAGG's, zoals deze in hoofdstuk 4 op basis van de historische ontwikkeling werd ingeschat, veel te hoog is. Het groeipercentage voor klinisch psychologen, werkzaam in de RIAGG's, wordt daarom naar beneden bijgesteld op het percentage dat door de respondenten wordt genoemd, namelijk op $10 \%$ in de komende 5 jaar. Verder wordt het groeipercentage voor de medische kleuterdagverblijven naar beneden 


$$
-45-
$$

bijgesteld. Op basis van de in de desbetreffende paragraaf geschetste ontwikkeling is het niet aannemelijk dat er hier groei zal plaatsvinden. Bovendien wordt de werkgelegenheid voor klinisch psychologen werkzaam bij Justitie, waarvoor eerder nog geen gegevens beschikbaar waren, als aparte categorie in de prognose opgenomen. 


\section{CONFRONTATIE VAN VRAAG EN AANBOD: TWEE VARIANTEN}

\subsection{Varianten}

In de voorgaande hoofdstukken is steeds slechts één prognosevariant gepresenteerd, respectievelijk als uitgangspunt genomen. Aangezien bij de prognose een nogal flinke onzekerheid optreedt wegens allerlei niet kwantificeerbare ontwikkelingen, worden hierna twee varianten gepresenteerd, een hoge en een lage variant. De hoge variant gaat uit van de meest gunstige situatie: een optimistische groeiverwachting (min of meer de voortzetting van de historische ontwikkeling) en een hoge vervangingsvraag. De lage variant gaat uit van de minst gunstige situatie: een pessimistische groeiverwachting (min of meer de verwachtingen van de respondenten of de ondergrens van de statistische onzekerheid) en een lage vervangingsvraag.

De ontwikkeling van het aanbod wordt niet als variant opgenomen, omdat de onzekerheden hier veel kleiner zijn. Het overgrote deel van de toekomstige uitstroom uit het universitaire onderwijs is immers reeds aan de studie begonnen, zodat de omvang van de onzekere instroom nauwelijks effect heeft op de orde van grootte van de geprognosticeerde uitstroom. Er is wel sprake van een onzeker aandeel van klinisch psychologen in het totaal aantal afstuderende psychologen. De gebruikte gegevens zijn echter onvoldoende om op basis hiervan varianten op te stellen.

\subsection{Confrontatie van vraag en aanbod}

De berekeningswijze van de totale vraag naar klinisch psychologen gedurende de komende zes jaar is als volgt. Allereerst worden de groei- en vervangingspercentages, die berekend zijn voor een periode van vijf jaar (1-1-1990 - 1-1-1995), omgerekend tot percentages voor zes jaar (1-1-1990 tot en met 31-12-1995). Daarna wordt de toename van de werkgelegenheid berekend door per sector de groei te vermenigvuldigen met het arbeidsvolume in 1990. Daarbovenop komt de vervangingsvraag per sector (deze is ook omgerekend). Vervolgens wordt dit aantal vermenigvuldigd met de P/A-verhouding om te komen tot een prognose in werkzame personen. Hieruit volgt dan de totale vraag naar klinisch psychologen. De resultaten voor beide varianten zijn 
weergegeven in de tabellen 8 (hoge variant) en 9 (lage variant) 16.

De gevolgde berekeningswijze leidt in de hoge variant tot een totale vraag naar nieuwkomers over de periode 1990-1995 (uitbreidingsvraag en vervangingsvraag) van 600 fulltime eenheden. Op basis van het huidige aantal gewerkte uren per psycholoog betekent dit extra werkgelegenheid voor 700 psychologen.

In de lage variant betekent dit een totale vraag naar nieuwkomers over de periode 1990-1995 (uitbreidingsvraag en vervangingsvraag) van 450 fulltime eenheden. Op basis van het huidige aantal gewerkte uren per psycholoog betekent dit extra werkgelegenheid voor 500 psychologen.

Het totale aanbod bestaat hoofdzakelijk uit nieuwe afstudeerders. Hierbij ontstaat het probleem dat studenten tegenwoordig zelf een vakkenpakket samenstellen, zodat niet meer duidelijk is na te gaan wie wel en wie niet als klinisch psycholoog valt aan te merken. Er zal volgens de methode uit hoofdstuk 3 toch een indeling worden gemaakt, maar daarvoor geldt dat deze slechts een ruwe indicatie geeft van het werkelijke aantal. Daarbovenop komen de klinisch psychologen die op dit moment als werkzoekende staan ingeschreven bij het arbeidsbureau. Zoals in hoofdstuk 3 is gesteld, wordt slechts de helft van de werkzoekenden zonder baan in 1990 tot het arbeidsaanbod gerekend, ondermeer omdat een aantal werklozen wegens langdurige werkloosheid waarschijnlijk niet meer voldoet aan de eisen die aan klinisch psychologen worden gesteld of geen baan als klinisch psycholoog meer ambieert. Het totale aanbod over zes jaar bestaat dan uit ongeveer 800 werkzoekenden +4100 afstudeerders $=4900 \mathrm{klinisch}$ psychologen. Het is van belang om er nog eens op te wijzen dat dit aanbod meer afstudeerrichtingen omvat dan de afstudeerrichting met de naam klinische psychologie.

\subsection{Conclusie}

Aangezien door het loslaten van de afstudeerspecialisatie bij het doctoraalexamen de scheiding tussen klinisch psychologen en overige psychologen erg vaag wordt, volstaan we met op te merken dat uit de berekeningen volgt

16. In de tabellen zijn niet de zelfstandig gevestigde psychologen opgenomen. Uit een indicatief onderzoek is gebleken dat het hier mogelijk ongeveer 125 fte betreft. Bij een groei van bijvoorbeeld $10 \%$ betekent dit voor de uiteindelijke vraag slechts een tiental extra psychologen. 
dat het aanbod de komende zes jaar waarschijnlijk ruim voldoende is om in de vraag naar klinisch psychologen vanuit de gezondheidszorg te voorzien. Aangezien de werkgelegenheidspositie van klinisch psychologen nu al tamelijk ongunstig is, is het redelijk te veronderstellen dat deze situatie in de nabije toekomst niet zal veranderen en de werkloosheid voor klinisch psychologen waarschijnlijk hoog zal blijven.

Omdat de lijst met klinische afstudeerrichtingen nogal ruim is, zal evenwel lang niet iedere psycholoog die hier als potentieel aanbod is beschouwd ook daadwerkelijk als klinisch psycholoog werkzaam willen zijn. Mede hierom zullen ongetwijfeld klinisch psychologen werk vinden in andere sectoren dan hier zijn onderscheiden (zoals de zakelijke dienstverlening of het onderwijs), maar daarvoor hadden ze waarschijnlijk geen specifieke opleiding tot klinisch psycholoog hoeven te volgen.

Gezien de ongunstige arbeidsmarktperspectieven en de hoge onzekerheid die prognoses nu eenmaal eigen is, lijkt het raadzaam om de arbeidsmarktsituatie van klinisch psychologen permanent te volgen via een monitoringsysteem. De basis van een dergelijk systeem kan worden gevormd door een actueel gegevensbestand over de werkgelegenheid van klinisch psychologen. Dit gegevensbestand zou minimal de informatie van het huidige NIP-ledenbestand moeten omvatten 17 . Vanuit een dergelijk monitoringsysteem is het dan tamelijk eenvoudig om regelmatig een actuele bijstelling van de werkgelegenheidsprognose voor klinisch psychologen op te stellen.

17. Men kan het systeem ook opzetten via de uitstroom van de universiteiten. Zie hiervoor Van Dam, Heijke en Ramaekers, Ontwerp van een arbeidsmarktscanner voor academici, ROA-R-1989/3, Maastricht en de toepassing van de scanner op de afgestudeerden van de Rijksuniversiteit Limburg: Ramaekers en Heijke, Proefonderzoek arbeidsmarktscanner afgestudeerden Rijksuniversiteit $L$ imburg, ROA-W-1990/3, Maastricht. 
Tabel 8. Bijgestelde prognose werkgelegenheidsgroei voor klinisch psychologen, 1990-1995 volgens de hoge variant

Intramurale gezondheidszorg

$$
\begin{gathered}
\text { arbeidsvolume } \\
1990
\end{gathered}
$$

Ziekenhuizen

Psychiatrische ziekenhuizen

TBS-inrichtingen

Verpleeghuizen

Zwakzinnigeninrichtingen

Medische kindertehuizen

Medische kleuterdagverblijven

Inr. voor zintuiglijk gehand.

Totaal

Vervangingsvraag $12,6 \%$

\section{Extramurale gezondheidszorg}

School artsendiensten 23

800

RIAGG

CAD

Overig

Eerstel ijnspraktijken

Totaal

Vervangingsvraag $16,1 \%$

\section{Overige sectoren}

Justitie

Gevangeni swezen

Kinderbescherming

Totaal

Vervangingsvraag $14,8 \%$

Totale vraag naar nieuwkomers:

390

466

40

59

145

12

30

13

1155

53

12

245

1133

33

12

45 uitbreidings-
vraag $\%$

totale

vraag

10

7

18

12

10

0

0

13

100

150

0

13

10

0

13

140

180

24

12

10

10

600

Bron: ROA 
Tabel 9. Bijgestelde prognose werkgelegenheidsgroei voor klinisch psychologen, 1990-1995 volgens de lage variant

Intramurale gezondheidszorg

arbeidsvolume

Ziekenhuizen

Psychiatrische ziekenhuizen

TBS-inrichtingen

Verpleeghuizen

Zwakzinnigeninrichtingen

Medische kindertehuizen

Medische kleuterdagverblijven

Inr. voor zintuiglijk gehand.

Totaal

Vervangingsvraag $10,3 \%$

\section{Extramurale gezondheidszorg}

School artsendiensten

RIAGG

CAD

Overig

Eerstelijnspraktijken

Totaal

Vervangingsvraag $14,5 \%$

Overige sectoren

Justitie

Gevangeni swezen

Kinderbescherming

Totaal

Vervangingsvraag $12,8 \%$
1990

390

466

40

59

145

12

30

13

1155

uitbreidings-

vraag \%

totale

vraag
6

$6-1$

12

0

$-1$

$-1$

11
0

2

1

$\begin{array}{rr}23 & 0 \\ 800 & 11 \\ 53 & 7 \\ 12 & 0 \\ 245 & 11\end{array}$

Bron: ROA 


\section{LITERATUURLIJST}

Centraal Bureau voor de Statistiek (1981..1987), Intramurale Gezondheidszorg, Den Haag.

Centraal Bureau voor de Statistiek (1982), Economische Basistellingen: gezondheidszorg 1982, Den Haag.

Centraal Bureau voor de Statistiek (1982), Standaard bedrijfsindeling bedrijfstelling 1978, Den Haag.

Centraal Bureau voor de Statistiek (1986), Compendium Gezondheidsstatistiek Nederland 1986, Den Haag.

Centraal Bureau voor de Statistiek (1987), Maandstatistiek van de bevolking, Den Haag.

Centraal Bureau voor de Statistiek (1989), Maandstatistiek van de gezondheidszorg, Den Haag.

Centraal Planbureau (1983), Vooruitberekening van het trendmatige arbeidsaanbod tussen 1980 en 2010, Den Haag.

Centraal Planbureau (1989), Macro Economische Verkenning 1990, Den Haag.

Commissie Ramingen Kwartaire Sector (1983), Over voorzieningen, gebruik en personee 1 in de kwartaire sector 1983-1987, Eindrapport van de Commissie Ramingen Kwartaire Sector, Ministerie van Binnenlandse Zaken/Sociaal en Cultureel Planbureau, Den Haag.

Coppens, I., en M. Tupan-Wenno (1989), Werkloosheidscijfers hoger opgeleiden, HW/T-verkenning no. 38, Zoetermeer.

Dam, J.W. van, J.A.M. Heijke en G.W.M. Ramaekers,(1989), Ontwerp van een arbeidsmarktscanner voor academici, ROA-R-1989/3, Maastricht.

Dijkstra, C., en J. Bannenberg (1986), Er zijn te veel klinisch psychologen, In: De Psycholoog, xxi, 4.

Elseviers, VSNU en HBO-raad (1988), Elseviers Studie Almanak, 1989, Anno Ventura, Amsterdam.

Giels, R.J. van (1989), Waar vind je als afgestudeerd psycholoog nog een baan?, Psychologisch Laboratorium KUN, Nijmegen.

Grip, A. de, J.A.M. Heijke, R.J.P. Dekker (1989), De arbeidsmarkt naar opleiding en beroep in 1992, ROA-R-1989/8, Maastricht.

Groot, W., en M. van Tits (1989), Vraag naar en aanbod van arbeid in 4 WVC sectoren, IVA, Tilburg.

Holzer, F.H.J.M. (1984), Is er toekomst voor psychologen ? In: De Psycholoog, xiv, 6.

Kerkhof, A.J.F.M., en G.I. Engels (1986), Werkgelegenheid als gelegenheidsargument In: De Psycholoog, xxi. 
Krijnen, G., en J. van den Berg (1976), Toekomstige ontwikkelingen op de arbeidsmarkt voor psychologen, In: De Psycholoog, xi, 4.

Mensen, Th., en Van den Burgh (1989), DIA-onderzoek, Groningen.

Ministerie van Sociale Zaken en Werkgelegenheid (1989), Rapportage Arbe idsmarkt 1989, Den Haag.

Nationaal Ziekenhuisinstituut (1987), Statistiek personeelssterkte 1986: Algemene Ziekenhuizen, Utrecht.

Nationale Raad voor de Volksgezondheid (1988), Rapport klinisch psycholoog in ziekenhuizen en verpleeghuizen, Zoetermeer.

Ramaekers, G.W.M. en J.A.M. Heijke, (1990) Proefonderzoek arbeidsmarktscanner afgestudeerden Rijksuniversiteit Limburg, ROA-W-1990/3, Maastricht.

Rooij, J. van, en P.F.M. Verhaak (1989), Psychologen in de eerste lijn, NIVEL, Utrecht.

Ruyter, D. de (1988), Psychologen op de arbeidsmarkt, KUN, Nijmegen.

Schaufeli, W.B., en A. de Vries (1987), Werk en werkloosheid onder klinisch psychologen, In: De Psycholoog, xxiii, 7.

Sociaal en Cultureel Planbureau (1984), Trendrapport Kwartaire Sector 19831990, SCP-Cahier 43, Rijswijk.

Sociaal en Cultureel Planbureau (1986), Memorandum kwartaire sector 19861990, SCP-Cahier 52, Rijswijk.

Sociaal en Cultureel Planbureau (1989), Trendrapport Kwartaire Sector 19701993, SCP-Cahier 67, Rijswijk.

Sociaal en Cultureel Planbureau/Centraal Planbureau (1984), Arbeidsvraag en arbeidsaanbod in de gezondheidszorg op lange termijn, Project Personeelsvoorziening Kwartaire Sector, Bulletin no. 5, Den Haag.

Taakgroep Studentenramingen (1988), Wetenschappelijk Onderwijs Ramingen Studenten Aantallen 1988-2004, Den Haag.

Taakgroep Studentenramingen (1989), Wetenschappelijk Onderwijs Ramingen Studenten Aantallen 1989-2005, Den Haag.

Tupan-Wenno, M.0. (1988), Werkloosheidscijfers hoger opgeleiden, HW/Tverkenning no.33, Zoetermeer.

Tweede Kamer der Staten-Generaal (1988), Financieel Overzicht Zorg 1989, vergaderjaar 1988-1989, 20 848, nrs 1-2.

Tweede Kamer der Staten-Generaal (1989), Financieel Overzicht Zorg 1990, vergaderjaar 1989-1990.

WAGG (1987..1989), Personee 1 in de AGGZ 1986, 1987 en 1988, Utrecht.

Wenno, M.0. (1987), Werkloosheidscijfers hoger opgeleiden, HW/T-verkenning no. 28, Zoetermeer 


\section{BIJLAGE 1: OVERZICHT VAN DE GEGEVENS IN HET NIP-LEDENBESTAND}

Peildatum: 12-1989

alle richtingen

$\%$

44,1

77,6

19,9

2,3

Afgestudeerden nieuwe stijl

Registratie klinische psych.

Aantal personen

4199

klinische richtingen

$\%$

47,4

77,6

20,6

2,3

56,3

3295

Belangrijkste hoofdrichtingen binnen de klinische richtingen:

- klinische psychologie

- ontwikkelingspsychologie

- kinder- en jeugdpsychologie

- persoonlijkheidsleer

Verdeling naar leeftijdsgroepen:

\begin{tabular}{lcc}
\hline categorie & $\begin{array}{c}\text { mannen } \\
\%\end{array}$ & $\begin{array}{c}\text { vrouwen } \\
\%\end{array}$ \\
& & \\
\hline & & 0,2 \\
onbekend & 0,1 & 0,8 \\
$20-24$ jaar & 0,0 & 12,8 \\
$25-29$ jaar & 4,6 & 22,1 \\
$30-34$ jaar & 12,4 & 20,9 \\
$35-39$ jaar & 23,8 & 18,9 \\
$40-44$ jaar & 25,9 & 10,9 \\
$45-49$ jaar & 14,6 & 6,9 \\
$50-54$ jaar & 8,6 & 4,2 \\
$55-59$ jaar & 6,0 & 2,0 \\
$60-64$ jaar & 3,4 & 0,4 \\
$65-$ jaar en ouder & 0,4 &
\end{tabular}

Bron: ROA/NIP

* Hierin zijn alleen mensen opgenomen met een betaalde baan van minimaal 12 uur per week. 
BIJLAGE 2: STUDIERICHTINGEN DIE KUNNEN OPLEIDEN TOT KLINISCH PSYCHOLOOG*

UVA:

Kinder- en jeugdpsychologie

Klinische psychologie

Ontwikkelingspsychologie

Vergelijkende en fysiologische psychologie

VU:

Kinder- en jeugdpsychologie

Klinische psychologie

Vergelijkende en fysiologische psychologie

RUG:

Klinische psychologie

Ontwikkelingspsychologie

Persoonlijkheidspsychologie

RUL:

Biologische psychologie

Klinische psychologie

Ontwikkelingspsychologie

Persoonlijkheidspsychologie

KUN:

Klinische psychologie

Neuro- en revalidatiepsychologie

Ontwikkelingspsychologie

Psychogerontologie

Vergelijkende en fysiologische psychologie

KUB:

Gezondheidspsychologie

RUU:

Arbeids- en bewustzijnspsychologie

Biologische psychologie

Klinische psychologie

$\mathrm{RL}$ :

Geestelijke gezondheidkunde (Faculteit der Gezondheidswetenschappen**

* Deze lijst heeft deels een arbitrair karakter. Hij is tot standgekomen op basis van Elseviers studie Almanak 1989 (Elseviers, VSNU en HBO-raad, 1988 ) en in overleg met de begeleidingscommissie vastgesteld. Door het arbitraire karakter van de lijst kunnen er afstudeerrichtingen zijn die hier wellicht ten onrechte niet zijn opgenomen en is de aanwezigheid van andere afstudeerrichtingen betwistbaar.

** Over de mogelijkheid voor afgestudeerden van deze afstudeerrichting om zich te laten registreren in het NIP-register wordt nog overleg gevoerd tussen de Faculteit der Gezondheidswetenschappen en het NIP. 


\section{BIJLAGE 3: PROGNOSE VAN HET AANTAL AFSTUDEERDERS}

De door WORSA gebruikte sleutel voor psychologie is gelijk aan die voor de andere studierichtingen, uitgezonderd de Medische en Landbouwrichtingen:

\begin{tabular}{|c|c|c|c|c|c|c|c|c|}
\hline jaar & 1 & 2 & 3 & 4 & 5 & 6 & 7 & 8 \\
\hline percentage & 0 & 0 & 0 & 5 & 20 & 56 & 15 & 4 \\
\hline
\end{tabular}

De afstudeercoëfficiënten zijn:

\begin{tabular}{|c|c|c|c|c|c|c|c|c|c|}
\hline jaar & 1 & 2 & 3 & 4 & 5 & 6 & 7 & 8 & Totaal \\
\hline percentage & 0 & 0 & 0 & 3,1 & 12,2 & 34,2 & 9,2 & 2,4 & 61,0 \\
\hline
\end{tabular}

De door WORSA gebruikte afstudeersleutel voor gezondheidswetenschappen is gelijk voor alle Medische studierichtingen en Gezondheidswetenschappen:

\begin{tabular}{llllrrrrr}
\hline jaar & 1 & 2 & 3 & 4 & 5 & 6 & 7 & 8 \\
percentage & 0 & 0 & 0 & 15 & 60 & 19 & 5 & 1 \\
\hline
\end{tabular}

De afstudeercoëfficiënten zijn:

\begin{tabular}{llllcccccc}
\hline jaar & 1 & 2 & 3 & 4 & 5 & 6 & 7 & 8 & Totaal \\
percentage & 0 & 0 & 0 & 11,9 & 47,4 & 15,0 & 4,0 & 0,8 & 79,0 \\
\hline
\end{tabular}

\begin{tabular}{lrrr} 
Jaar & total psychologie & klinisch richting & $\begin{array}{c}\text { klinische richting } \\
\text { incl. GGK }\end{array}$ \\
\hline & & & \\
1979 & 744 & 591 & \\
1980 & 798 & 533 & \\
1981 & 770 & 515 & \\
1982 & 774 & 505 & \\
1983 & 797 & 531 & 914 \\
1984 & 855 & 573 & 627 \\
1985 & 921 & 614 & 668 \\
1986 & 988 & 662 & 692 \\
1987 & 1838 & 1219 & 724 \\
1988 & 1359 & 893 & 706 \\
1989 & & & 708 \\
1990 & 906 & 608 & 707 \\
1991 & 974 & 645 & \\
1992 & 1009 & 657 & \\
1993 & 1046 & 681 & \\
1994 & 1019 & 662 & 664 \\
1995 & 1026 & 663 & \\
& 1028 & & \\
& & &
\end{tabular}


De eerste kolom geeft het jaar van afstuderen. De tweede kolom geeft het aantal afstudeerders in psychologie aan (volgens onze reconstructie van de WORSA-methode). De derde kolom geeft een benadering van het aantal afstudeerders in de klinische richtingen aan. In de laatste kolom staat de som van afstudeerders in een klinische richting en afstudeerders in de Geestelijke Gezondheidkunde (een afstudeerrichting binnen Gezondheidswetenschappen). Deze som wordt pas vanaf 1988 gegeven omdat pas in dat jaar de eerste studenten in deze richting van Gezondheidswetenschappen afstudeerden. 


\begin{tabular}{llll}
\hline & 1987 & 1989 & 1990 \\
\hline & & 1641 & 1664 \\
aantal personen & 1351 & $59,1 \%$ & $59,5 \%$ \\
\hline
\end{tabular}

belangrijke beroepen waaronder men ingeschreven staat:

\begin{tabular}{|c|c|c|c|}
\hline & $\%$ & $\%$ & \\
\hline psycholoog & 26,0 & 36,1 & . \\
\hline klinisch psycholoog & 49,6 & 31,4 & . \\
\hline kinderpsycholoog & 9,7 & 8,0 & . \\
\hline
\end{tabular}

belangrijke laatst vervulde beroepen:

\begin{tabular}{lrrr}
\hline & $\%$ & $\%$ & $\%$ \\
\hline & & & 49,9 \\
geen & 50,6 & 50,0 & 9,6 \\
psycholoog & 9,8 & 10,2 & 10,0 \\
klinisch psycholoog & 14,1 & 9,3 & \\
\hline
\end{tabular}

belangrijke sectoren waarin het laatste beroep vervuld werd:

\begin{tabular}{lrrr}
\hline & $\%$ & $\%$ & $\%$ \\
& & & 49,9 \\
& & & 1,1 \\
geen laatste beroep & 50,6 & 50,0 & 1,2 \\
Uitzendbureaus & 1,0 & 1,2 & 1,7 \\
Algemene overheid & 1,8 & 1,8 & 7,1 \\
Hoger Beroepsonderwijs & 1,7 & 1,6 & 1,6 \\
Wetenschappelijk onderwijs & 11,3 & 8,1 & 2,4 \\
Algemene ziekenhuizen & 2,1 & 1,4 & 0,7 \\
Psychiatrische inrichtingen & 2,7 & 2,6 & 2,4 \\
Kindertehuizen & 1,0 & 0,6 & 1,0 \\
Ambulante geestelijke & & 2,6 & 0,7 \\
gezondheidszorg & 3,0 & & 7,9 \\
Div. maatschappelijke & 1,0 & 0,3 & 0,7 \\
organisaties & 1,6 & 8,4 & \\
Algemeen maatschappelijke org. & 1,8 & & \\
Persoonlijke dienstverlening & & & \\
\hline
\end{tabular}

Bron: Ministerie van Sociale Zaken en Werkgelegenheid 
BIJLAGE 5: BEZETTE ARBEIDSPLAATSEN IN DE INTRAMURALE GEZONDHEIDSZORG PER 31-12

9311 algemene ziekenhuizen

$\begin{array}{rrrrrrrrr}1980 & 1981 & 1982 & 1983 & 1984 & 1985 & 1986 & 1987 & 1988 \\ 2754 & 2845 & 2777 & 2847 & 2804 & 2905 & 2775 & 2808 & 2916 \\ 99965 & 101237 & 101191 & 99553 & 98774 & 99749 & 98100 & 98160 & 98311\end{array}$

9312 academische ziekenhuizen

$\begin{array}{crrrrrrrrr}416 \text { medisch + soc wet. } & 1053 & 1055 & 1154 & 1749 & 1849 & 1907 & 2289 & 2389 & 2715 \\ \text { totaal } & 21769 & 21389 & 22368 & 22304 & 22391 & 22447 & 25305 & 25747 & 26586\end{array}$

9313 categorale ziekenhuizen

416 medisch + soc wet.

totaal

$\begin{array}{rrrrrrrrr}462 & 543 & 545 & 538 & 604 & 572 & 607 & 662 & 555 \\ 9955 & 10210 & 10384 & 10179 & 10314 & 9983 & 9925 & 10169 & 9143\end{array}$

931 ziekenhuizen totaal

totaal

4269
$131689 \quad 132$

$4442 \quad 4476 \quad 5134$

5257

5384

5671

5859

6186

$132837 \quad 133943 \quad 132036$

$131479 \quad 132179$

133329

$134075 \quad 134041$

9321 psychiatrische ziekenhuizen

416 medisch + soc wet. 1138

totaal

24708

$\begin{array}{rr}1223 & 1256 \\ 25508 & 25968\end{array}$

1292

1323

1348

1420

1482

1551

$25846 \quad 25956$

26168

26614

27092

27325

9331 zwakzinnigeninrichtingen

416 medisch + soc wet. totaal

440
26334

502

480

475

487

493

488

47

29712

524

$29712 \quad 30969$

9341 verpleeghuizen (voor somatische patiënten)

$\begin{array}{lrrr}416 \text { medisch + soc wet. } & 192 & 170 & 181 \\ \text { totaal } & 18415 & 18547 & 17313 \\ & & & \\ \text { verpleeghuizen (voor psycho-geriatrische patiënten) }\end{array}$

416 medisch + soc wet.

126
10253

111

124

171
12097

163
11877

$28385 \quad 29159$

9343 verpleeghuizen (gecombineerd)

416 medisch + soc wet. $\quad 182$

totaal

18294

204

219

213

255

285

24117

352

25526

28393

375

30025

934 verpleeghuizen (totaal)

416 medisch + soc wet. totaal

$\begin{array}{rr}500 & 486 \\ 46962 & 48152\end{array}$

524
48759

581

601
52535

683
53527

746

684

707

$56035 \quad 56612$

9313.3 medische kindertehuizen

416 medisch + soc we

totaal

$\begin{array}{rr}51 & 39 \\ 864 & 772\end{array}$

24
681

30

31

31

53877

9384 medische kleuterdagverblijven

416 medisch + soc wet.

totaal

$\begin{array}{rr}38 & 56 \\ 859 & 949\end{array}$

47
969

48

613

670

25

26

22

$652 \quad 630$

9431.3 inr. voor zintuiglijk gehand.

416 medisch + soc wet. 23 totaal

1171

30

.

$27 \quad 30$

30
1099

31
1060

53

1078

60

60
087

54

60

61

Totaal

416 medisch + soc we

$6448 \quad 6778$

6834

7590

7783

totaal $232587 \quad 236400$

238866

239627

241215

8027
243072

28

29

1051

1009

8434

$8616 \quad 9086$

Bron: Centraal Bureau voor de Statistiek 
BIJLAGE 6: ARBEIDSVOLUME IN DE EXTRAMURALE ZORG

\begin{tabular}{|c|c|c|c|c|c|c|c|}
\hline & 1982 & 1983 & 1984 & 1985 & 1986 & 1987 & 1988 \\
\hline AGGZ & 4709 & 4832 & 4867 & 5053 & 5277 & 5406 & 5513 \\
\hline w.v. psych. & 686 & 720 & 768 & 815 & 815 & 745 & 594 \\
\hline w.v. ov.acad. & 926 & 973 & 1001 & 1099 & 1151 & 1051 & 890 \\
\hline$C A D$ & 825 & 857 & 893 & 923 & 921 & 917 & 920 \\
\hline w.v. psych. & & & & 58 & 53 & 54 & 54 \\
\hline w.v. ov.acad. & 87 & 97 & 106 & 111 & 104 & 105 & 105 \\
\hline RIAGG & & 3500 & 3536 & 3791 & 4057 & 4206 & 4313 \\
\hline w.v. overige acad & demici & 795 & 820 & 947 & 1010 & 933 & 773 \\
\hline OVERIG & & 784 & 402 & 339 & 299 & 284 & 279 \\
\hline w.v. overige acac & demici & 140 & 72 & 41 & 37 & 13 & 12 \\
\hline schoolartsend. & 1499 & 1461 & 1461 & 1481 & 1451 & 1441 & 1430 \\
\hline w.v. psychologen & 22 & 22 & 22 & 24 & 17 & 17 & 23 \\
\hline
\end{tabular}

Bron: Centraal Bureau voor de Statistiek 
BIJLAGE 7: VERDELING VAN DE NIP-PSYCHOLOGEN NAAR WERKSECTOR (AFGESTUDEERD NA 1984)

Sector

Percentage

Maatschappelijke dienstverlening

24,7

w.v. RIAGG

CAD

Praktijken van eerstelijns psychologen

Overig

9,7

0,2

4,9

9,9

Intramurale Gezondheidszorg

31,4

w.v. Ziekenhuizen

12,0

Psychiatrische ziekenhuizen

10,7

Overig

8,7

Onderwijs

17,6

Zakelijke dienstverlening

11,3

Overige dienstverlening

6,3

Overig

8,7

Bron: ROA/NIP 
BIJLAGE 8: GEGEVENS VAN EERSTELIJNS PSYCHOLOGEN (dd. 6-1988)

$\begin{array}{llll} & \text { psychologen } & \text { psychologen } & \text { totaal } \\ \text { Jaar } & \text { zonder ander } & \text { met ander } & \\ \text { van aanvang } & \text { dienstverband } & \text { dienstverband } & \end{array}$

\begin{tabular}{|c|c|c|c|c|c|c|}
\hline & $n$ & $\%$ & $n$ & $\%$ & $n$ & $\%$ \\
\hline-1960 & - & - & 14 & 4 & 14 & 3 \\
\hline $1961-1965$ & 2 & 1 & 10 & 3 & 12 & 2 \\
\hline $1966-1970$ & - & - & 21 & 7 & 21 & 4 \\
\hline $1971-1975$ & 2 & 1 & 36 & 12 & 38 & 8 \\
\hline $1976-1980$ & 21 & 11 & 58 & 19 & 79 & 16 \\
\hline $1981-1985$ & 103 & 55 & 115 & 38 & 218 & 44 \\
\hline $1985-$ & 61 & 32 & 51 & 17 & 112 & 23 \\
\hline totaal & 189 & & 305 & & 494 & \\
\hline $\begin{array}{l}\text { Aantal uren } \\
\text { per week }\end{array}$ & $n$ & $\%$ & $n$ & $\%$ & $n$ & $\%$ \\
\hline $4-5$ & 7 & 3 & 37 & 13 & 44 & 9 \\
\hline $6-10$ & 33 & 16 & 87 & 30 & 120 & 24 \\
\hline $11-15$ & 21 & 10 & 36 & 13 & 57 & 12 \\
\hline $16-20$ & 39 & 19 & 56 & 20 & 95 & 19 \\
\hline $21-25$ & 12 & 6 & 22 & 8 & 34 & 7 \\
\hline $26-30$ & 22 & 11 & 21 & 7 & 43 & 9 \\
\hline $31-35$ & 20 & 19 & 11 & 4 & 31 & 6 \\
\hline $36-40$ & 36 & 17 & 11 & 4 & 47 & 10 \\
\hline \multirow[t]{2}{*}{$41-$} & 19 & 9 & 3 & 1 & 22 & 4 \\
\hline & 209 & & 284 & & 493 & \\
\hline \multicolumn{7}{|l|}{ gemiddeld } \\
\hline aantal uren & 25,2 & & 15,9 & & 19,8 & \\
\hline
\end{tabular}

n $\%$

algemeen ziekenhuis psychiatrisch ziekenhuis

RIAGG

$43 \quad 16$

opleidingsinstituut

onderzoeksinstituut

71

26

advies/hulpbureau

bedrijf

totaal 
BIJLAGE 9: SCP-RAMING PERSONEEL, in 1000-tallen, 1983-1990

$\begin{array}{lclllllll} & 1983 & 1984 & 1985 & 1986 & 1987 & 1988 & 1989 & 1990 \\ \begin{array}{l}\text { Ziekenhuizen } \\ \text { basisraming } \\ \text { personeel }\end{array} & 132,1 & 132,6 & 133,2 & 133,8 & 134,4 & 135,1 & 135,8 & 136,4 \\ \begin{array}{l}\text { jaarmutatie } \\ \text { demografische raming }\end{array} & & 0,4 & 0,4 & 0,5 & 0,5 & 0,5 & 0,5 & 0,5 \\ \begin{array}{l}\text { personeel } \\ \text { jaarmutatie }\end{array} & 132,1 & 133,0 & 134,0 & 135,0 & 135,9 & 136,8 & 137,8 & 138,7 \\ & & 0,7 & 0,7 & 0,7 & 0,7 & 0,7 & 0,7 & 0,6\end{array}$

Psychiatrische ziekenhuizen

basisraming

$\begin{array}{lclllllll}\text { personeel } & 26,2 & 26,4 & 26,6 & 26,8 & 27,0 & 27,2 & 27,3 & 27,5 \\ \begin{array}{l}\text { jaarmutatie } \\ \text { demografische raming }\end{array} & & 0,8 & 0,8 & 0,7 & 0,7 & 0,7 & 0,7 & 0,7 \\ \begin{array}{l}\text { personeel } \\ \text { jaarmutatie }\end{array} & 26,2 & 26,3 & 26,4 & 26,5 & 26,6 & 26,7 & 26,7 & 26,8 \\ & & 0,4 & 0,4 & 0,4 & 0,3 & 0,3 & 0,3 & 0,3\end{array}$

Zwakzinnigeninrichtingen

basisraming

personeel

$27,9 \quad 28,2 \quad 28,4 \quad 28,7 \quad 29,0$

jaarmutatie

demografische raming

personeel

jaarmutatie

$\begin{array}{llll}27,9 & 28,2 & 28,4 & 28,7\end{array}$

29,2

29,4

29,6

$27,9 \quad 28,0 \quad 28,1 \quad 28,2 \quad 28$,

$0,8 \quad 0,8$

0,7

$0,4 \quad 0,4 \quad 0,4 \quad 0,3$

0,3

28,4

28,5

28,5

Verpl eeghuizen

basisraming

personeel

jaarmutatie

demografische raming

personeel

jaarmutatie

$\begin{array}{llllllll}50,0 & 51,5 & 53,0 & 54,5 & 56,0 & 57,4 & 58,8 & 60,0 \\ & 3,0 & 2,9 & 2,9 & 2,6 & 2,5 & 2,4 & 2,1 \\ 50,0 & 51,3 & 52,6 & 53,8 & 55,0 & 56,2 & 57,4 & 58,4 \\ & 2,5 & 2,4 & 2,4 & 2,2 & 2,1 & 2,0 & 1,7\end{array}$

Inrichtingen voor zintuiglijk gehandicapten

basisraming

personeel

jaarmutatie

$\begin{array}{llllllll}1,2 & 1,1 & 1,1 & 1,0 & 1,0 & 0,9 & 0,9 & 0,9\end{array}$

demografische raming

personeel

jaarmutatie

$\begin{array}{llllllll}1,2 & 1,1 & 1,1 & 1,0 & 1,0 & 0,9 & 0,9 & 0,9 \\ & -4,4 & -4,6 & -4,9 & -5,1 & -5,4 & -5,7 & -6,0 \\ 1,2 & 1,2 & 1,2 & 1,2 & 1,2 & 1,2 & 1,2 & 1,2 \\ & 0,4 & 0,4 & 0,4 & 0,3 & 0,3 & 0,3 & 0,3\end{array}$

Ambulante geestelijke gezondheidszorg

basisraming

personeel

jaarmutatie

demografische raming

personee1

jaarmutatie

$\begin{array}{llllllll}4,9 & 4,9 & 4,9 & 5,0 & 5,0 & 5,0 & 5,1 & 5,1 \\ & 0,7 & 0,7 & 0,7 & 0,7 & 0,7 & 0,6 & 0,6 \\ & & & & & & & \\ 4,9 & 4,9 & 4,9 & 5,0 & 5,0 & 5,0 & 5,1 & 5,1 \\ & 0,7 & 0,7 & 0,7 & 0,7 & 0,7 & 0,6 & 0,6\end{array}$


BIJLAGE 10: PROGNOSE VOORZIENINGENGEBRUIK INTRAMURALE ZORG 1988-1995

\begin{tabular}{|c|c|c|c|c|}
\hline Sector & 1988 & 1990 & 1993 & 1995 \\
\hline \multicolumn{5}{|l|}{ Ziekenhuizen } \\
\hline demoraming & 102 & 104 & 107 & 109 \\
\hline basisraming & 102 & 103 & 106 & 108 \\
\hline demoraming personeel & 103 & 108 & 116 & 121 \\
\hline basisraming personeel & 103 & 106 & 113 & 118 \\
\hline \multicolumn{5}{|c|}{ Psychiatrische ziekenhuizen } \\
\hline demoraming & 102 & 103 & 105 & 106 \\
\hline basisraming & 104 & 109 & 116 & 121 \\
\hline demoraming personeel & 103 & 103 & 104 & 105 \\
\hline basisraming personeel & 104 & 106 & 110 & 112 \\
\hline \multicolumn{5}{|l|}{ Verpleeghuizen } \\
\hline demoraming & 105 & 109 & 114 & 118 \\
\hline basisraming & 105 & 109 & 114 & 118 \\
\hline demoraming personeel & 105 & 110 & 116 & 120 \\
\hline basisraming personeel & 105 & 110 & 116 & 120 \\
\hline \multicolumn{5}{|c|}{ Zwakzinnigeninrichtingen } \\
\hline demoraming & 101 & 103 & 104 & 105 \\
\hline basisraming & 102 & 103 & 106 & 108 \\
\hline demoraming personeel & 103 & 106 & 108 & 109 \\
\hline basisraming personeel & 105 & 106 & 111 & 114 \\
\hline \multicolumn{5}{|c|}{ Extramurale geestelijke gezondheidszorg ${ }^{*}$} \\
\hline demoraming & 103 & 106 & 109 & 112 \\
\hline basisraming & 114 & 128 & 154 & 169 \\
\hline
\end{tabular}

* Bij deze categorie worden geen ramingen voor de personeelssterkte gemaakt omdat de historische gegevens met betrekking tot het gebruik ontbreken.

Bron: ROA/SCP 
Uitgangspunt bij de bepaling van de vervangingsvraag is de verhouding tussen het aantal werkzame psychologen in $1995\left(E_{t+5}\right)$ ten opzichte van het aantal werkzame psychologen in $1990\left(E_{t}\right)$ per leeftijdscohort en geslacht. Hierbij worden de landelijke deelnemingspercentages per leeftijdscohort en geslacht gebruikt, zoals deze door het CPB (CPB, 1983) zijn gepubliceerd. Deze deelnemingspercentages worden onder meer beïnvloed door arbeidsongeschiktheid, pensionering en de deelname op de arbeidsmarkt van gehuwde vrouwen. De deelnemingspercentages $\left(D p_{t}\right)$ geven de verhouding tussen de beroepsbevolking (BB) en de potentiële beroepsbevolking (PB) weer:

$B B_{t}=D p_{t} * P B_{t} 18$

en dus ook:

$B B_{t+5}=D p_{t+5} * P B_{t+5}$

De verandering van de beroepsbevolking $\left(\mathrm{BB}_{t+5} / \mathrm{BB}_{t}\right)$ valt te schrijuen als:

$\left(\mathrm{BB}_{t+5} / \mathrm{BB}_{t}\right)=\left(\mathrm{Dp}_{t+5} * \mathrm{~PB}_{t+5}\right) /\left(\mathrm{Dp}_{t} * \mathrm{~PB}_{t}\right)$

$\mathrm{Nu}$ wordt veronderstel dat veranderingen in de potentiële beroepsbevolking alleen kunnen optreden ten gevolge van sterfte. Dat wil zeggen:

$P B_{t+5}=(1-\rho) P B_{t}$

Hierbij worden alleen de sterftekansen naar geslacht per leeftijdsgroep (CBS, 1987) van invloed op $\rho$ geacht. Emigratie en immigratie worden dus buiten beschouwing gelaten. Dan kan de verandering in de beroepsbevolking geschreven worden als:

$$
\begin{aligned}
\mathrm{BB}_{t+5} / \mathrm{BB}_{t}= & \left(D \mathrm{D}_{t+5} / D \mathrm{p}_{t}\right) *\left(\mathrm{~PB}_{t+5} / \mathrm{PB}_{t}\right)= \\
& \left(D \mathrm{D}_{t+5} / D \mathrm{p}_{t}\right) *(1-\rho)
\end{aligned}
$$

De deelnemingspercentages naar leeftijdscohort en naar geslacht zijn op elk

18. Deze formules zijn verschillend voor leeftijdscohorten en geslacht, maar omwille van de duidelijkheid worden de bijbehorende subscripten in deze en volgende formules weggelaten. 
tijdstip bekend. Bovendien is $\rho$ bekend, zodat de verandering in de beroepsbevolking berekend kan worden. Er wordt nu verondersteld dat de ontwikkeling in het aantal werkenden parallel loopt aan de ontwikkeling van de beroepsbevolking:

$\left(E_{t+5} / E_{t}\right)=\left(B B_{t+5} / B B_{t}\right)=\left(D p_{t+5} / D p_{t}\right) *(1-\rho)$

Uit bovenstaande formule kan op eenvoudige wijze een uitvalpercentage per geslacht en leeftijdscohort berekend worden. Combinatie van deze uitvalpercentages per geslacht en leeftijdscohort met de procentuele leeftijdsverdeling van de werkenden in een bepalde sector levert het vervangingspercentage voor deze sector.

De belangrijkste beperking van deze methode is dat de landelijke deelnemingspercentages ook van toepassing worden verklaard op de psychologen, zonder rekening te houden met de typische eigenschappen van dit beroep. Een andere beperking is dat emigratie en immigratie verwaarloosd worden, maar geeft waarschijnlijk geen grote vertekening van de resultaten. Een derde nadeel is het gelijkstellen van de ontwikkeling van het aantal werkenden met de ontwikkeling van de totale beroepsbevolking. Deze aanname impliceert dat werkende en werkloze psychologen identieke sterftecijfers en uittredekansen hebben.

Een belangrijk voordeel van deze methode is dat de berekende uitvalpercentages worden gecombineerd met de procentuele leeftijdsverdeling per sector, zodat specifieke kenmerken van psychologen via deze leeftijdsverdeling kunnen doorwerken in de vervangingsvraag. Dit levert waarschijnlijk wel enige compensatie voor de nogal beperkende aannamen die gemaakt zijn. 


\section{BIJLAGE 12: DE ARBEIDSDUUR IN DE INTRAMURALE GEZONDHEIDSZORG}

Gemiddelde arbeidsduur naar instelling: (als percentage van de contractuele arbeidsduur)

\begin{tabular}{lcccccc} 
& 1980 & 1983 & 1984 & 1985 & 1986 & 1987 \\
\hline ziekenhuizen & & & & & & 0,92 \\
psychiatrische ziekenhuizen & 0,93 & 0,93 & 0,92 & 0,93 & 0,93 & 0,95 \\
inrichtingen voor zwakzinnigen & 0,90 & 0,85 & 0,86 & 0,85 & 0,85 & 0,84 \\
verpleeghuizen & 0,84 & 0,83 & 0,81 & 0,81 & 0,79 & 0,81 \\
overige instelingen & 0,79 & 0,76 & 0,76 & 0,74 & 0,72 & 0,74 \\
totaal & & & & & & 0,61 \\
& 0,90 & 0,88 & 0,88 & 0,88 & 0,88 & 0,88 \\
\hline
\end{tabular}

Gemiddelde arbeidsduur naar geslacht (per 1-12-87): (als percentage van de contractuele arbeidsduur)

\begin{tabular}{lll} 
& mannen & vrouwen \\
\hline ziekenhuizen & 0,94 & 0,85 \\
psychiatrische ziekenhuizen & 0,92 & 0,76 \\
inrichtingen voor zwakzinnigen & 0,87 & 0,73 \\
verpleeghuizen & 0,79 & 0,68 \\
overige instellingen & 0,70 & 0,55 \\
totaal & 0,92 & 0,78 \\
\hline
\end{tabular}

Indexcijfers voor de contractuele arbeidsduur, 1980=100

\begin{tabular}{lrrrrrrrr} 
SBI & 1982 & 1983 & 1984 & 1985 & 1986 & 1987 & 1988 & 1989 \\
\hline 90 & 99,6 & 98,3 & 97,4 & 96,1 & 94,4 & 94,4 & 94,4 & 94,4 \\
92 & 99,6 & 99,5 & 99,4 & 99,0 & 98,4 & 98,4 & 98,3 & 98,3 \\
93 & 100,0 & 98,6 & 98,1 & 97,3 & 94,7 & 94,7 & 94,7 & 94,7 \\
$94 / 95$ & 99,9 & 98,3 & 97,4 & 96,4 & 95,0 & 94,9 & 94,9 & 94,9 \\
\hline
\end{tabular}

Bron: CBS 


\section{BIJLAGE 13: LIJST MET GESPREKSTHEMA'S}

De volgende thema's zouden wij graag met u willen bespreken:

1. Wat is uw mening over de voorlopige prognose van het ROA en de veronderstellingen die aan deze prognose ten grondslag liggen?

2. Kunt $u$ aangeven waar en hoeveel extra terreinwinst of -verlies voor $k l i n i s c h$ psychologen t.o.v. andere disciplines te behalen valt en onder welke omstandigheden?

3. Wat zijn alles bij elkaar genomen uw verwachtingen m.b.t. de werkgelegenheid in uw sector en die van klinisch psychologen in het bijzonder en waarom ? Welke bijzondere factoren acht $u$ in de toekomst mogelijk van betekenis voor de werkgelegenheidsontwikkeling en hoe waarschijnlijk is het optreden van deze factoren?

ad 1. Verwacht $u$ een lagere of hogere groei van de werkgelegenheid van klinisch psychologen in uw arbeidsveld dan door ons wordt verwacht, en waarom?

In welke mate zal er sprake zijn van herintrede?

ad 2. In welke functies zou de positie van klinisch psychologen kunnen toenemen?

In welke functies zal de positie van klinisch psychologen afnemen?

Gegeven de ontwikkeling van de sector, de desbetreffende functies en de concurrentiepositie van de klinisch psychologen, wat zal dan de in vijf jaar te boeken terreinwinst of -verlies kunnen zijn in termen van werkgelegenheid?

Welke nieuwe arbeidsvelden kunnen in de komende vijf jaar van belang worden voor de werkgelegenheid van klinisch psychologen?

ad 3. Hoe zal naar uw verwachting het aantal banen voor klinisch psychologen zich in de komende vijf jaren in uw arbeidsveld ontwikkelen?

In hoeverre zal de werkgelegenheid voor klinisch psychologen afhankelijk zijn van prijspolitieke matregelen die worden genomen in de gezondheidszorg?

Welke gevolgen heeft het spanningsveld tussen budgetfinanciering en gewenste kwaliteit op de aanname van nieuw personeel?

Wat zal de betekenis zijn van het buitenland voor de werkgelegenheid van klinisch psychologen? (Zowel de invloed van buitenlandse psychologen voor Nederland als de invloed van het buitenland voor 
Nederlandse psychologen)

Welke gevolgen kan de instelling van de post-doctorale opleiding klinische psychologie voor het aannamebeleid cq. de werkgelegenheidspositie van klinisch psychologen hebben?

Welke gevolgen kan de instelling van de wet Beroepen individuele gezondheidszorg (BIG) hebben voor de werkgelegenheidspositie van de klinisch psycholoog?

Welke andere factoren acht $u$ de komende vijf jaar eveneens van belang voor de arbeidsmarktpositie van de klinisch psycholoog in uw sector?

Maastricht, 28 maart 1990

NIP/8809/ROA/TB 